\title{
Advanced Sulfur Control Concepts for Hot Gas Desulfurization Technology
}

\author{
Quarterly Report \\ January 1 - March 31, 1997
}

Work Performed Under Contract No.: DE-AC21-94MC30012

For

U.S. Department of Energy

Office of Fossil Energy

Federal Energy Technology Center Morgantown Site

P.O. Box 880

Morgantown, West Virginia 26507-0880

By

Department of Chemical Engineering

Louisiana State University

Baton Rouge, Louisiana 70803

DISTRIBUTION OF THIS DOCUMENT IS UNLIMITED 


\section{DISCLAIMER}

Portions of this document may be illegible in electronic image products. Images are produced from the best available original document. 


\section{EXECUTIVE SUMMARY}

Experimental effort on Task 3.2 - Laboratory Development - was completed during the quarter. Professor Harrison, project Principal Investigator, reviewed the overall project status in a presentation in Morgantown in January 1997. The presentation emphasized the favorable results recently achieved in the sulfidation of $\mathrm{CeO}_{2}$ by $\mathrm{H}_{2} \mathrm{~S}$ and the regeneration of $\mathrm{Ce}_{2} \mathrm{O}_{2} \mathrm{~S}$ by $\mathrm{SO}_{2}$. Successful removal of approximately $99 \%$ of the $\mathrm{H}_{2} \mathrm{~S}$ from the sulfidation gas to levels of about $100 \mathrm{ppmv}$ (or lower), and the production of approximately $12 \%$ elemental sulfur $\left(\right.$ as $\mathrm{S}_{2}$ ) in the regeneration product gas were highlights. Incremental funding of $\$ 60,000$ and a one-year time extension to continue the cerium-sorbent work was approved. The test plan for the additional. work was submitted.

I On the experimental front, the quarter represented a transition period which included final tests in the preliminary phase of the study, and initial work in the more detailed phase. Final effort in the preliminary phase included a ten-cycle test at "standard" sulfidation and regeneration conditions with little or no sorbent deterioration. In this multicycle test the cause of the high prebreakthrough $\mathrm{H}_{2} \mathrm{~S}$ concentration plateau was identified as being due to residual sulfur compounds downstream of the sorbent bed and in the transfer tubing between the reactor and analytical system. Chemical cleaning by flowing a $\mathrm{H}_{2} / \mathrm{N}_{2}$ mixture through the reactor and downstream tubing at high temperature was effective in reducing the prebreakthrough $\mathrm{H}_{2} \mathrm{~S}$ plateau to the $400-500 \mathrm{ppmv}$ level. The use of high temperature air to remove sulfur compounds by converting them to $\mathrm{SO}_{2}$ was even more effective. Prebreakthrough $\mathrm{H}_{2} \mathrm{~S}$ concentrations of 100 ppmv or less were achieved after oxidative cleaning.

In the initial test of the detailed experimental phase of the program, we investigated the effect of temperature on the regeneration reaction. Results of preliminary tests showed that the $\mathrm{Ce}_{2} \mathrm{O}_{2} \mathrm{~S}-\mathrm{SO}_{2}$ reaction did not occur at $350^{\circ} \mathrm{C}$, and all subsequent regeneration tests were at $600^{\circ} \mathrm{C}$ where the reaction was rapid. A series of regeneration tests between 450 and $700^{\circ} \mathrm{C}$ found essentially no reaction at $450^{\circ} \mathrm{C}$, and rapid and complete regeneration at higher temperature but with little effect of temperature on the reaction rate.

The original justification for the $\mathrm{CeO}_{2}$ sorbent study was the probability of the direct production of elemental sulfur during sorbent regeneration. Experimental results to date have confirmed this advantage. Primary disadvantages of $\mathrm{CeO}_{2}$ include reduced sulfur capacity (the sulfur content of $\mathrm{Ce}_{2} \mathrm{O}_{2} \mathrm{~S}$ is only $9 \mathrm{wt} \%$ compared to $33 \mathrm{wt} \%$ in pure $\mathrm{ZnS}$ ), and the less favorable thermodynamics of the $\mathrm{CeO}_{2}-\mathrm{H}_{2} \mathrm{~S}$ reaction compared to the $\mathrm{ZnO}-\mathrm{H}_{2} \mathrm{~S}$ reaction. The thermodynamics limitation led to the two-stage desulfurization concept with $\mathrm{CeO}_{2}$ used for bulk $\mathrm{H}_{2} \mathrm{~S}$ removal followed by a $\mathrm{ZnO}$ polishing step. Obviously, the attractiveness of the $\mathrm{CeO}_{2}$ process would be increased if the second desulfurization stage could be eliminated. Both experimental and thermodynamic evidence, based on the reduction of $\mathrm{CeO}_{2}$ to $\mathrm{CeO}_{n}(n<2)$ and subsequent reaction between $\mathrm{CeO}_{\mathrm{n}}$ and $\mathrm{H}_{2} \mathrm{~S}$, has been found which indicates that single-stage desulfurization may, indeed, be possible. We propose to examine this possibility during the remainder of the project. 
Significant progress has been made on the process analysis effort during the quarter. Detailed process flow diagrams along with material and energy balance calculations for six design case studies were completed in the previous quarter. Two of the cases involved twostage desulfurization with steam regeneration, three used two-stage desulfurization with $\mathrm{SO}_{2}$ regeneration, and the sixth was based on single-stage desulfurization with elemental sulfur recovery using the DSRP concept.

In the present quarter, major process equipment was sized for each of the six cases. Capital cost estimates indicated that two-stage desulfurization with $\mathrm{SO}_{2}$ regeneration could be accomplished with the least capital cost, followed by single-stage desulfurization with DSRP, and two-stage desulfurization with steam regeneration being the most capital intensive. The incremental capital cost required for single-stage desulfurization with DSRP was due primarily to the large air compressor required in the sorbent regeneration step. Capital costs were relatively insensitive to the operating temperature of the primary (first-stage) sorber and regenerator.

Preliminary annual operating and levelized total cost estimates were then completed for two design cases -- one involving two-stage desulfurization with $\mathrm{SO}_{2}$ regeneration and the second based on single-stage desulfurization with DSRP. These calculations used "base case" estimates of the unit costs of raw material and by-product chemicals and utilities. The final levelized cost in both cases was quite high, but the estimated annual levelized cost of the single-stage desulfurization with DSRP was about $60 \%$ less than that of two-stage desulfurization with $\mathrm{SO}_{2}$ regeneration.

Sorbent replacement cost, which was the dominant cost item in each case, was based upon an assumed sorbent replacement rate equal to $1 \%$ of the sorbent circulation rate, equivalent to an average sorbent life of 100 cycles. If either process is to be economically attractive, the sorbent replacement rate must be lowered considerably. This will reduce the cost of the cerium sorbent-based two-stage desulfurization process with $\mathrm{SO}_{2}$ regeneration at a faster rate than the cost of the zinc sorbent-based single-stage desulfurization process with DSRP. At some replacement rate the cerium sorbent process will become more economical as its lower capital requirement becomes a more important cost factor.

In future economic analysis, a number of parameters, including sorbent unit cost and sorbent replacement rate, will be varied to illustrate the sensitivity of the process cost to key items.

\section{CERIUM SULFIDATION AND REGENERATION}

The primary reactions of interest are:

$$
\begin{aligned}
2 \mathrm{CeO}_{2}(s)+\mathrm{H}_{2} \mathrm{~S}(g)+\mathrm{H}_{2}(g) & \rightarrow 2 \mathrm{Ce}_{2} \mathrm{O}_{2} \mathrm{~S}(s)+2 \mathrm{H}_{2} \mathrm{O}(g) \\
\mathrm{Ce}_{2} \mathrm{O}_{2} \mathrm{~S}(s)+\mathrm{SO}_{2}(g) & \rightarrow 2 \mathrm{CeO}_{2}(s)+\mathrm{S}_{2}(g)
\end{aligned}
$$


The research was originally justified on the basis of the potential for the direct production of elemental sulfur during the sorbent regeneration step. However, because $\mathrm{Ce}_{2} \mathrm{O}_{2} \mathrm{~S}(\mathrm{~s})$ is not available commercially, both the sulfidation and regeneration reactions must be studied.

Most early $\mathrm{CeO}_{2}$ sulfidation tests were performed at $800^{\circ} \mathrm{C}$ and $5 \mathrm{~atm}$ using a sulfidation gas containing $1 \% \mathrm{H}_{2} \mathrm{~S}, 10 \% \mathrm{H}_{2}$, and balance $\mathrm{N}_{2}$. Sulfidation is rapid and complete and good sulfur material balance closure has been achieved. The only negative result was an unexpectedly large $\mathrm{H}_{2} \mathrm{~S}$ concentration plateau prior to breakthrough. Near the end of the previous quarter, the cause of this plateau was tentatively attributed to sulfur contamination in the reactor system downstream of the sorbent bed. Sulfidation studies during the present quarter have examined the cause and elimination of the contamination and have studied sorbent durability through ten complete cycles. Evidence has been found in the literature suggesting that the sulfidation effectiveness of cerium sorbent in highly reducing, high temperature gases might be increased to the point that a single-stage desulfurization process using cerium sorbent might be feasible. This work is discussed in a subsequent section of this report.

Regeneration results continue to be favorable. The regeneration reaction is rapid and complete at $600^{\circ} \mathrm{C}$ and elemental sulfur concentrations (expressed as $S_{2}$ ) as high as $12 \%$ have been produced. The ten-cycle test completed during this quarter showed little, if any, sorbent deterioration. A series of tests in which the regeneration temperature was varied showed the reaction to be rapid and complete over the range of $500-700^{\circ} \mathrm{C}$. The effect of temperature on regeneration kinetics was quite small.

A summary of reaction conditions used in all experimental tests during the quarter is presented in Table 1. The first three cycles of run Ce-16 were completed in the previous quarter. All sulfidation runs were conducted at $800^{\circ} \mathrm{C}$ and $5 \mathrm{~atm}$ using $400 \mathrm{sccm}$ of feed gas containing $1 \% \mathrm{H}_{2} \mathrm{~S} / 10 \% \mathrm{H}_{2} /$ balance $\mathrm{N}_{2}$. Regeneration runs were at $1 \mathrm{~atm}$ using $200 \mathrm{sccm}$ of feed gas containing $12 \% \mathrm{SO}_{2} /$ balance $\mathrm{N}_{2} .600^{\circ} \mathrm{C}$ regeneration temperature was used in Ce16 , Ce-17, and Ce-18, while the regeneration temperature in the multiple cycles of Ce-19 was varied between 450 and $700^{\circ} \mathrm{C}$. The initial sorbent charge consisted of $6.0 \mathrm{~g} \mathrm{CeO}_{2}$ and $3.0 \mathrm{~g}$ of inert $\mathrm{Al}_{2} \mathrm{O}_{3}$ except in run $\mathrm{Ce}-18$ where the $\mathrm{Al}_{2} \mathrm{O}_{3}$ was omitted.

\section{Run Ce-16}

The primary purpose of this run was to test the durability of the $\mathrm{CeO}_{2}$ sorbent through ten complete sulfidation-regeneration cycles. In addition, initial effort testing different reactor cleaning procedures between regeneration and sulfidation cycles was instituted, and the sulfur material balance was carefully monitored.

$\mathrm{H}_{2} \mathrm{~S}$ concentrations in the sulfidation product gas as a function of time for cycles Ce$16 \mathrm{~s} 03$ through Ce-16s 10 are shown in Figures 1 and 2 . Figure 1 is the traditional 
Table 1. Summary of Reaction Test Conditions: $\mathrm{CeO}_{2}$ Sulfidation and-Régeneration January - March 1977

\begin{tabular}{|c|c|c|c|c|c|c|c|c|c|c|c|}
\hline Run & $\begin{array}{l}\mathrm{Ce}-16 \mathrm{~s} 04 \\
\text { through } \\
\mathrm{Ce}-16 \mathrm{~s} 10\end{array}$ & $\begin{array}{l}\mathrm{Ce}-16 \mathrm{rO} 4 \\
\text { through } \\
\mathrm{Ce}-16 \mathrm{r} 10\end{array}$ & $\begin{array}{c}\mathrm{Ce}-17 \mathrm{~s} 01 \\
\text { and } \\
\mathrm{Ce}-17 \mathrm{~s} 02\end{array}$ & $\begin{array}{l}\mathrm{Ce}-17 \mathrm{rO} 1 \\
\text { and } \\
\mathrm{Ce}-17 \mathrm{rO} 2\end{array}$ & $\mathrm{Ce}-18 \mathrm{~s} 01$ & $\begin{array}{c}\mathrm{Ce}-19 \mathrm{~s} 01 \\
\text { through } \\
\mathrm{Ce}-19 \mathrm{~s} 05\end{array}$ & Ce-19r01 & $\mathrm{Ce}-19 \mathrm{r} 02$ & Ce-19r03 & Ce-19r04 & Ce-19r05 \\
\hline Date & $\begin{array}{l}1 / 03 / 97- \\
1 / 18 / 97\end{array}$ & $\begin{array}{l}1 / 03 / 97- \\
1 / 18 / 97\end{array}$ & $\begin{array}{l}2 / 27 / 97- \\
2 / 28 / 97\end{array}$ & $\begin{array}{l}2 / 27 / 97- \\
2 / 28 / 97\end{array}$ & $3 / 14 / 97$ & $\begin{array}{l}3 / 25 / 97- \\
3 / 31 / 97\end{array}$ & $3 / 25 / 97$ & $3 / 26 / 97$ & $3 / 27 / 97$ & $3 / 28 / 97$ & $3 / 31 / 97$ \\
\hline
\end{tabular}

Reactor Packing

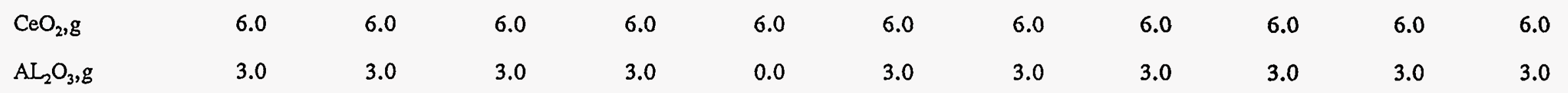

Reaction Conditions

Temp, ${ }^{\circ} \mathrm{C}$
Press, atm

Gas Composition

$\% \mathrm{H}_{2} \mathrm{~S}$
$\% \mathrm{SO}_{2}$
$\% \mathrm{H}_{2}$
$\% \mathrm{~N}_{2}$

Total Gas

Flow rate, SCCM
800

5

600

800

600

800

5

1

0

1

0

12

10

0

88

10

89

89

200

400

200

400

400

200

200

200

200

200 


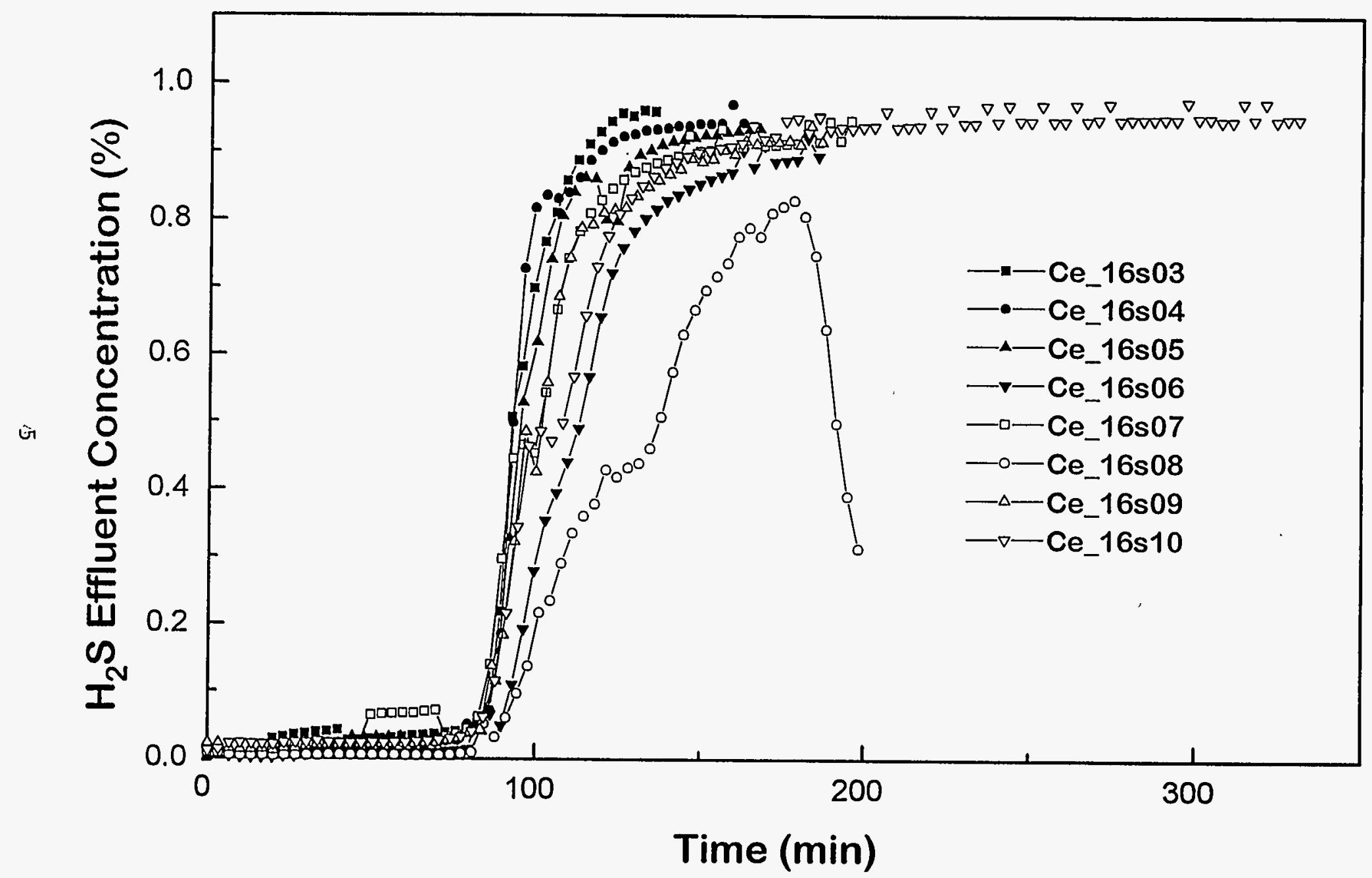

Figure 1. Sulfidation Breakthrough Curves for Tests Ce-16s03 through Ce-16s10. 


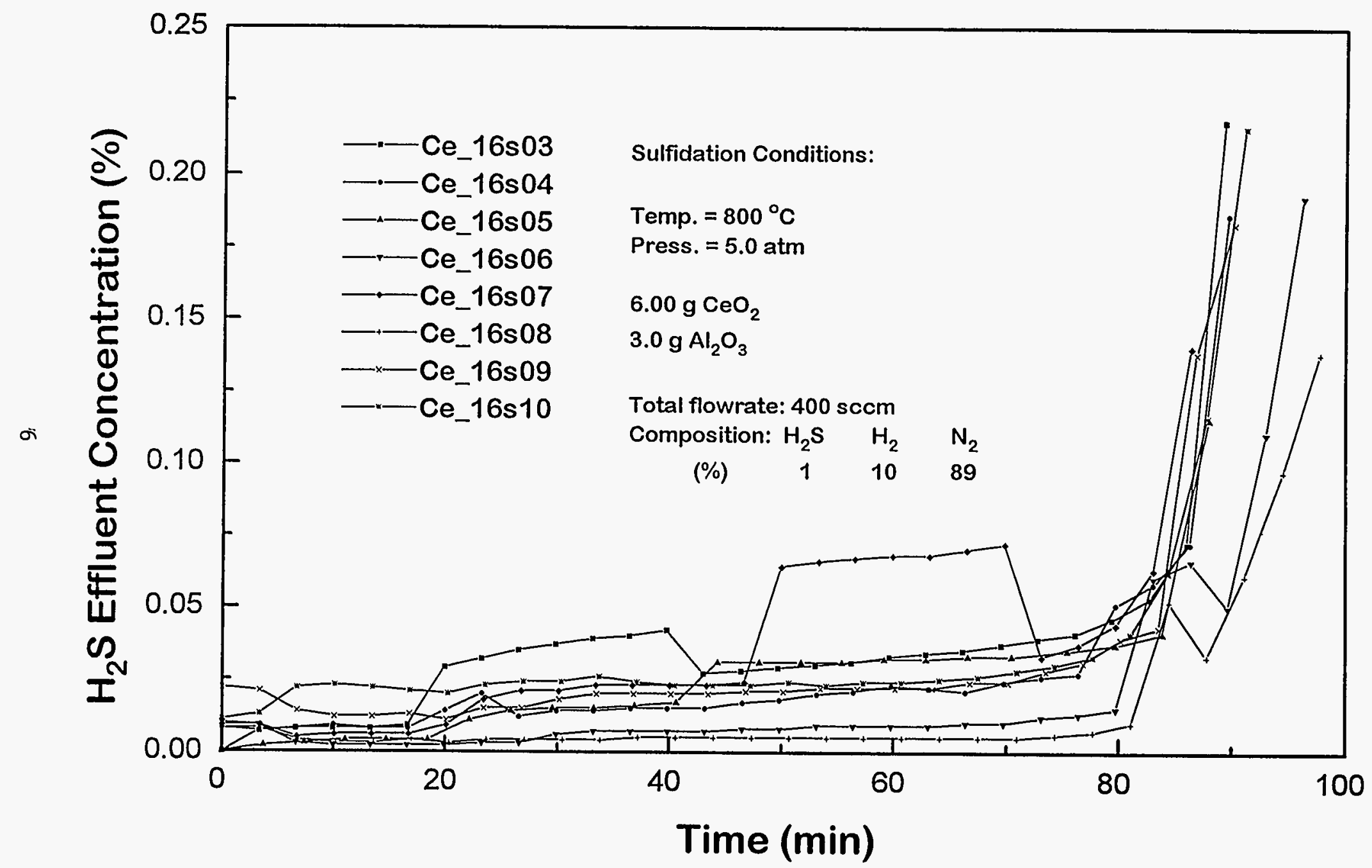

FIgure 2. Sulfidation Prebreakthrough Curves for Ce-16s03 through Ce-16s10. 
breakthrough curve showing the complete cycle results; in Figure 2 the concentration scale has been expanded to emphasize $\mathrm{H}_{2} \mathrm{~S}$ concentrations during the prebreakthrough period. All sulfidation tests, with the exception of $\mathrm{Ce}-16 \mathrm{~s} 08$, went to completion in the same general time period. In $\mathrm{Ce}-16 \mathrm{~s} 08$, the $\mathrm{H}_{2} \mathrm{~S}$ mass flow controller malfunctioned after about 175 minutes, which may also have been responsible for the earlier differences in the $\mathrm{H}_{2} \mathrm{~S}$ breakthrough curve for that cycle.

The important results from Figure 2 include the facts that initial $\mathrm{H}_{2} \mathrm{~S}$ concentrations were all equal to or less than $0.025 \% \mathrm{H}_{2} \mathrm{~S}(250 \mathrm{ppmv})$, and that, with the exception of the unexplained upset in $\mathrm{Ce}-16 \mathrm{~s} 07$ in the 50 to 70 minute period, the $\mathrm{H}_{2} \mathrm{~S}$ concentration was less than $0.05 \%$ ( $500 \mathrm{ppmv}$ ) for the first 80 minutes of each cycle. Of particular interest, the $\mathrm{H}_{2} \mathrm{~S}$ concentrations in Ce-16s06 and Ce16s08 were below $150 \mathrm{ppm}$ for 80 minutes. $\mathrm{H}_{2} \mathrm{~S}$ breakthrough time, taken as $0.05 \%(500 \mathrm{ppm})$, was approximately constant as shown in Figure 3. The times ranged from a low of 79.5 minutes in Ce-16s04 to a maximum of 84.3 minutes in Ce-16s05. The unexplained upset in Ce16s07 was ignored in determining the breakthrough time.

It was prior to $\mathrm{Ce}-16 \mathrm{~s} 03$ that the importance of cleaning the reactor system between regeneration and sulfidation cycles was first recognized. $\mathrm{A}_{2} / \mathrm{N}_{2}$ mixture was passed through the high temperature reactor to remove (at least partially) downstream sulfur compounds prior to each of the sulfidation cycles shown in Figures 1 and 2. The presence of residual sulfur was proven by the fact that significant $\mathrm{H}_{2} \mathrm{~S}$ concentrations were present when the $\mathrm{H}_{2} / \mathrm{N}_{2}$ cleaning gas was analyzed. In general, this cleaning step was effective in reducing the initial $\mathrm{H}_{2} \mathrm{~S}$ concentration to about 400 ppmv.

All ten regeneration cycles of run $\mathrm{Ce}-16$ used the same reaction conditions; $\mathrm{SO}_{2}$ breakthrough curves for all cycles are shown in Figure 4. With the exception of two samples -- one at 17 minutes in $\mathrm{Ce}-16 \mathrm{r} 03$ and the other at 10 minutes in $\mathrm{Ce}-16 \mathrm{r} 10$-- the results were almost identical. The first measurable quantity of $\mathrm{SO}_{2}$, about $1 \%$, was detected after 10 minutes, and by 23 minutes regeneration was effectively complete. The final steady-state $\mathrm{SO}_{2}$ content in the product gas ranged from 11.8 to $12.2 \%$.

Sulfur material balance results, expressed as percent of stoichiometric sulfur removed during sulfidation and liberated during regeneration, are presented in Figure 5. Results from the previous quarter (cycles 1 and 2) are included except for Ce-16s01 where an error was made in the sulfidation gas flow rate. Results from $\mathrm{Ce}-16 \mathrm{~s} 08$ are also omitted because of the mass flow controller malfunction.

Sulfur material balance closure in the eight sulfidation cycles of run Ce-16 included in Figure 5 ranged from a minimum of $75.0 \%$ in Ce- $16 \mathrm{~s} 02$ to a maximum of $96.8 \%$ in Ce16s10. Regeneration results ranged from a minimum of $86.0 \%$ of stoichiometric in $\mathrm{Ce}-16 \mathrm{r} 03$ to $92.6 \%$ of stoichiometric in $\mathrm{Ce}-16 \mathrm{r} 10$. Ideally, the sulfidation and regeneration results from a single cycle should be equal. That is, the quantity of sulfur removed during sulfidation should be equal to the quantity liberated during regeneration. Differences are 


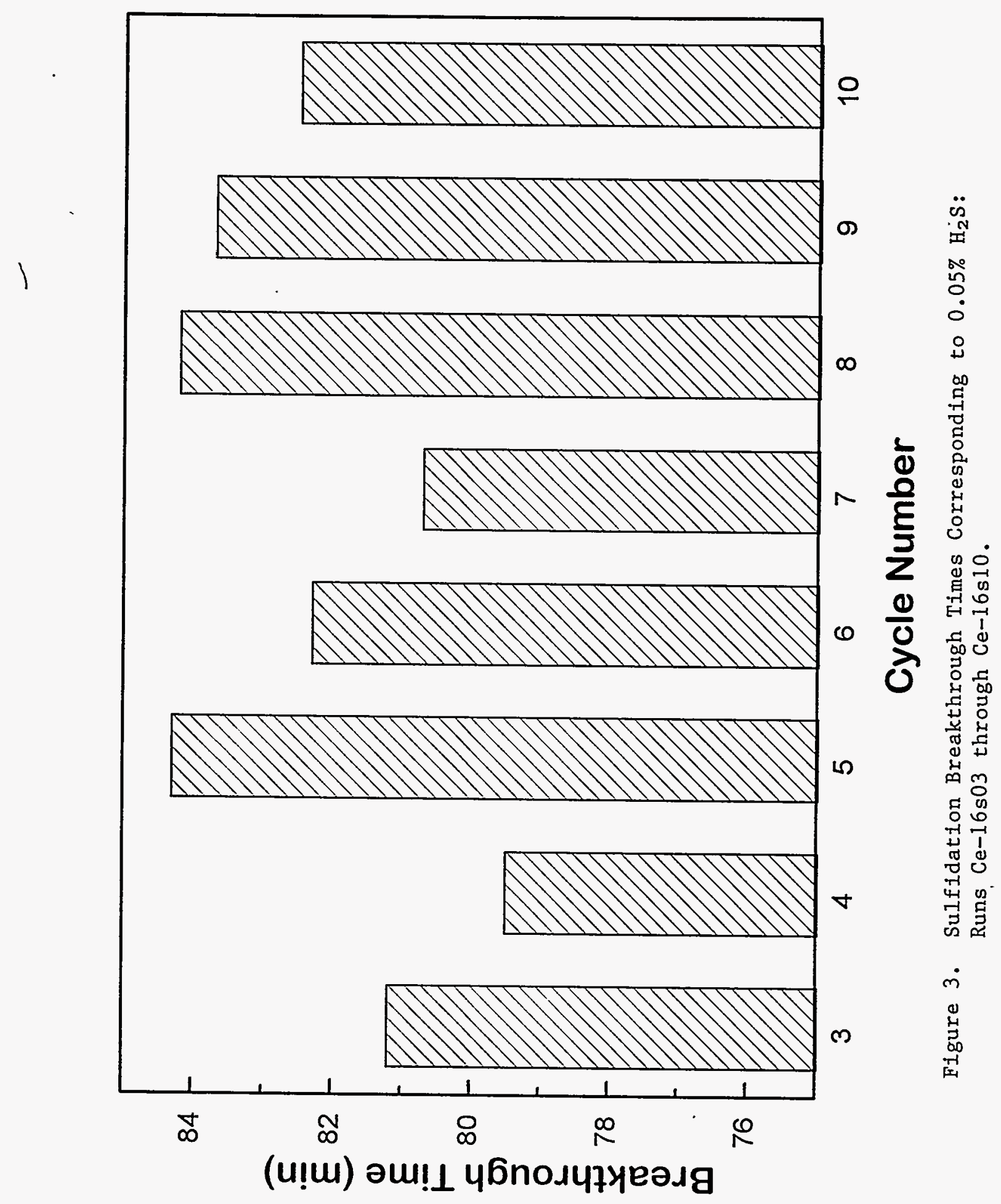




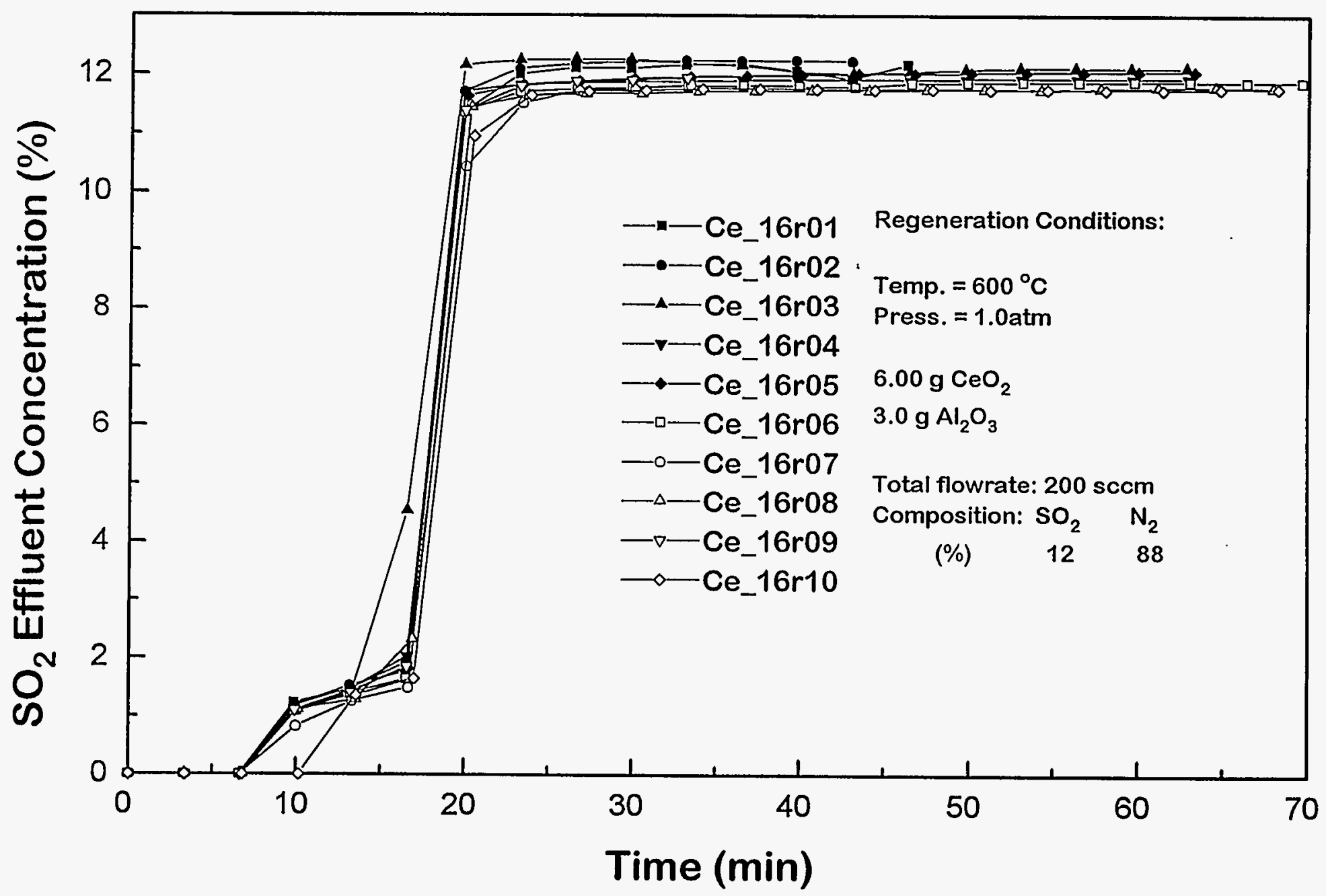

Figure 4. Regeneration Breakthrough Curves for Tests Ce-16r01 through Ce-16r10. 


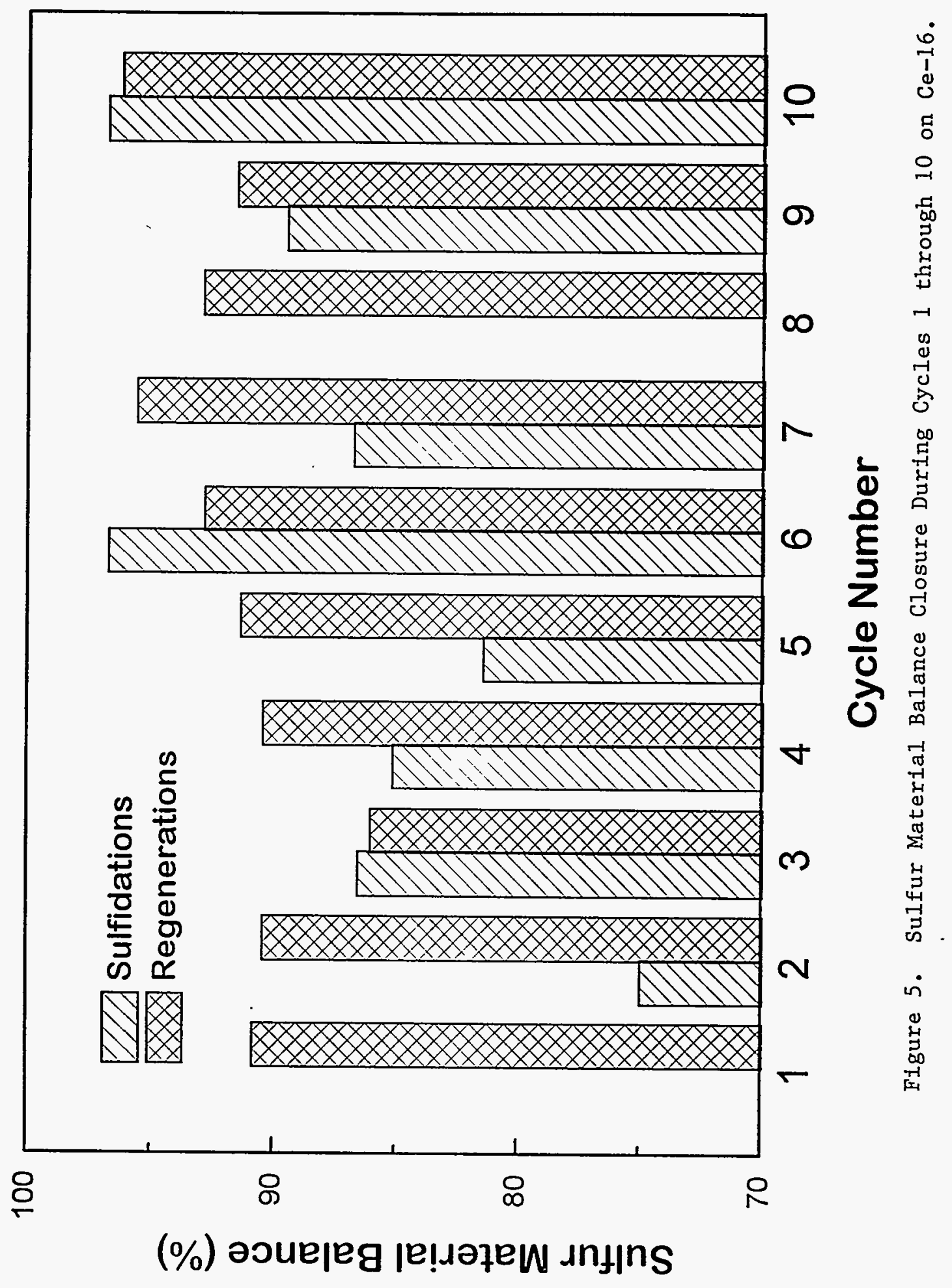


caused by errors in flow rates (mass flow controllers), product gas analysis, and numerical integration of the breakthrough curve data. The maximum difference occurred in cycle 5 where sulfur removal and liberation were $81.5 \%$ and $91.4 \%$ of stoichiometric, respectively. However, the agreement was quite good when results from all cycles are averaged. Sulfur removal in the eight sulfidation cycles in Figure 5 averaged $87.2 \%$ of stoichiometric $(88.9 \%$ if the low value associated with Ce-16s02 is omitted), while sulfur liberated in the ten regeneration cycles averaged $91.8 \%$ of stoichiometric.

The results of this extended ten-cycle run were quite favorable. The relative constancy of the slopes of the sulfidation and regeneration breakthrough curves, the small variation in breakthrough times, and the sulfur material balance closure all suggest little, if any, sorbent deterioration. In addition, the source of the elevated $\mathrm{H}_{2} \mathrm{~S}$ prebreakthrough concentration was identified and a method of reducing the concentration by about one order of magnitude was identified. It is important to recognize that the sulfur contamination problem would not exist in a commercial system where the reactor is not alternately exposed to sulfidation and regeneration conditions.

\section{Run Ce-17}

The primary purpose of two-cycle run Ce-17 was to continue to examine the effect of the severity of reactor cleaning on prebreakthrough $\mathrm{H}_{2} \mathrm{~S}$ concentration. While cleaning with $\mathrm{H}_{2} / \mathrm{N}_{2}$ was effective in reducing the prebreakthrough $\mathrm{H}_{2} \mathrm{~S}$ concentration to about 400 ppmv, this concentration was still larger than expected on the basis of thermodynamics. Prior to run $\mathrm{Ce}-17 \mathrm{~s} 01$ and following Ce-17r01, air flowed through the reactor at $850^{\circ} \mathrm{C}$ with downstream tubing at $360^{\circ} \mathrm{C}$. Approximately 150 hours at these conditions were required before $\mathrm{SO}_{2}$ disappeared from the product gas prior to $\mathrm{Ce}-17 \mathrm{~s} 01$. The air cleaning cycle lasted 10 hours before $\mathrm{Ce}-17 \mathrm{~s} 02$.

$\mathrm{H}_{2} \mathrm{~S}$ concentration-time results for the two sulfidation cycles are shown in Figure 6. The runs were terminated when the $\mathrm{H}_{2} \mathrm{~S}$ content reached about $0.2 \%$ (2000 ppmv) in order to minimize sulfur contamination downstream of the sorbent bed. The significant result is that

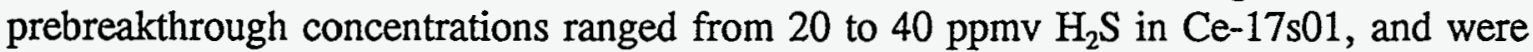
approximately constant at $40 \mathrm{ppmv}$ in Ce-17s02. It is important to realize that these low $\mathrm{H}_{2} \mathrm{~S}$ concentrations are, at best, approximate, since the sensitivity limit of the thermal conductivity detector for $\mathrm{H}_{2} \mathrm{~S}$ is about $100 \mathrm{ppmv}$. Although approximate, the results suggest that concentrations significantly below $100 \mathrm{ppmv}$ can be achieved. The fact that $\mathrm{Ce}-17 \mathrm{~s} 02$ concentrations were slightly larger may indicate that residual sulfur contamination remained after the abbreviated air cleaning cycle prior to $\mathrm{Ce}-17 \mathrm{~s} 02$.

Regeneration breakthrough curves for $\mathrm{Ce}-17 \mathrm{r} 01$ and $\mathrm{Ce}-17 \mathrm{r} 02$ are presented in Figure 7. Standard regeneration conditions were used and results in the two cycles were effectively equal. In both cycles, the $\mathrm{SO}_{2}$ concentration was zero in the first three samples $(\mathrm{t}<7 \mathrm{~min})$, increased to about $2 \%$ during the next three samples, and closely approached the feed 


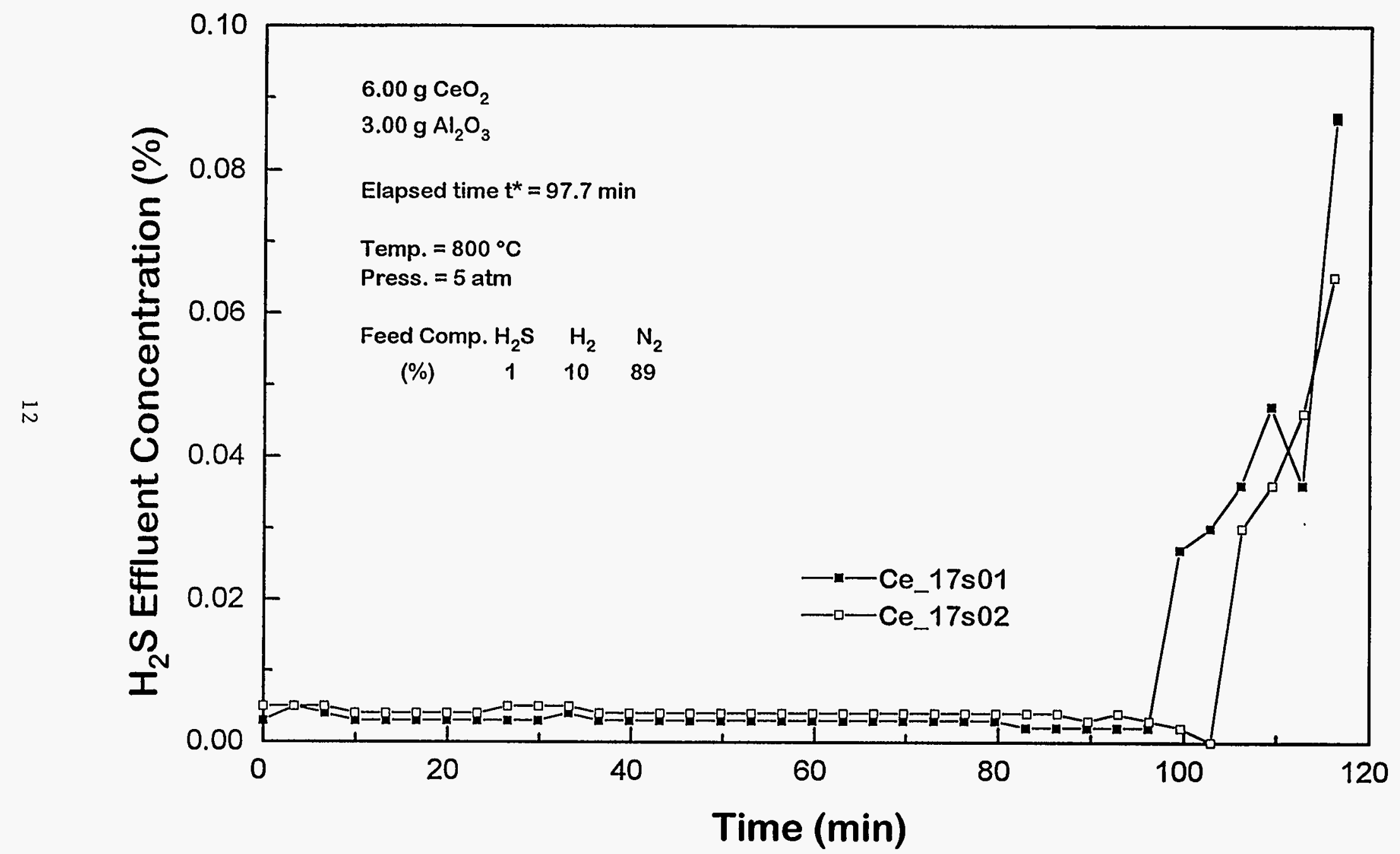

Figure 6. Sulfidation Response Curves: Run Ce-17s01 and Ce-17s̄02. 


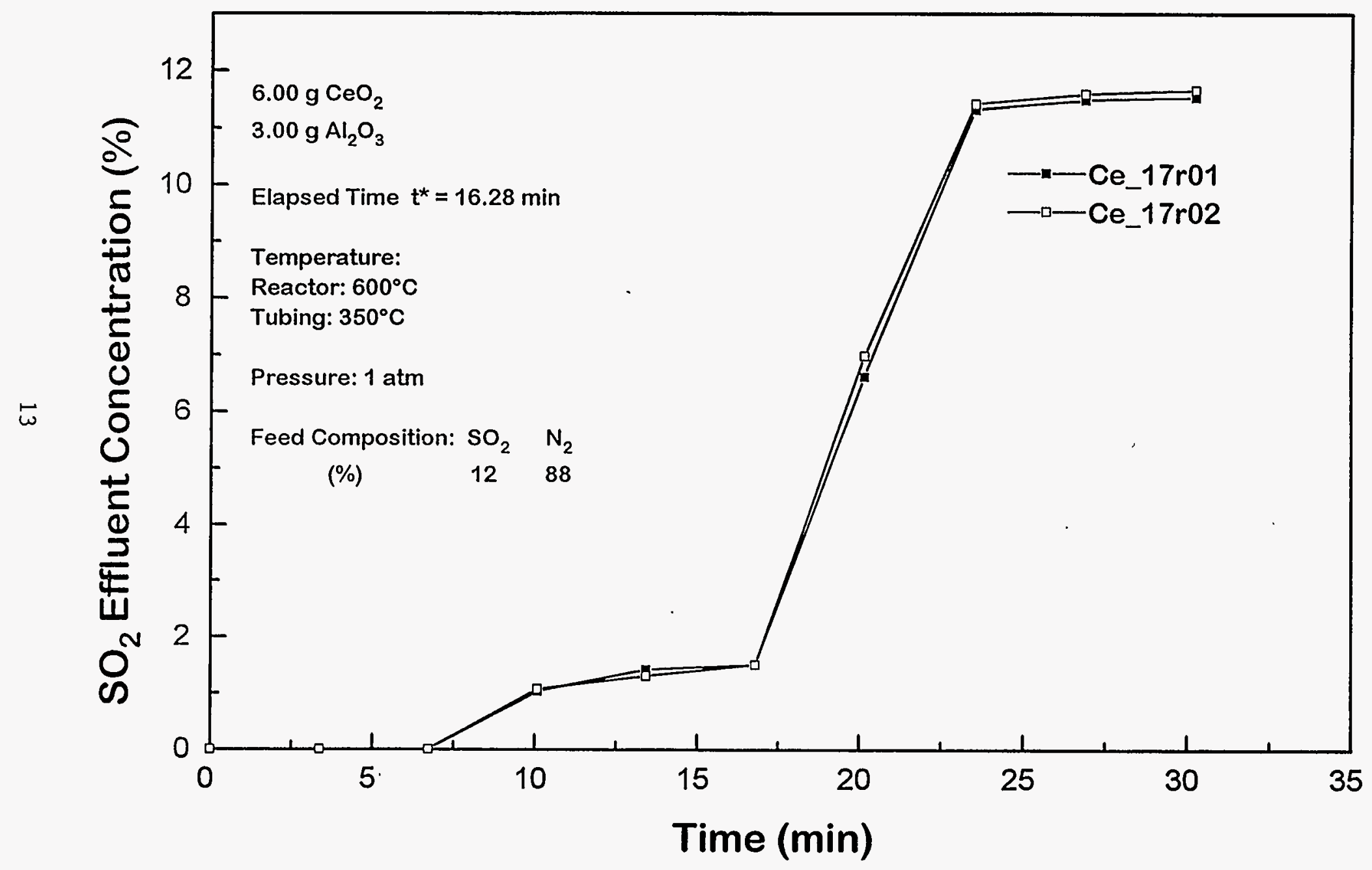

Figure 7: Regeneration Response Curves: Run Ce-17r01 and Ce-17 02 . 
composition of $12 \%$ by the eighth sample at about 23 minutes. Elemental sulfur concentration (considered as $S_{2}$ ) exceeded $10 \%$ for the first 17 minutes of each cycle.

\section{Run Ce-18}

In all recent cerium tests, the sorbent charge consisted of $\mathrm{CeO}_{2}$ and inert $\mathrm{Al}_{2} \mathrm{O}_{3}$ in a 2to-1 mass ratio. The $\mathrm{Al}_{2} \mathrm{O}_{3}$ was added to prevent sintering which occurred in earlier runs using pure $\mathrm{CeO}_{2}$. Originally a 1-to-1 mass ratio was used and this was later changed to the 2-to- 1 ratio without adverse effect. Completely eliminating the $\mathrm{Al}_{2} \mathrm{O}_{3}$ would permit the charge of $\mathrm{CeO}_{2}$ to be increased, and would extend the duration of the regeneration cycle and/or allow still higher $\mathrm{SO}_{2}$ concentrations to be used. However, severe sintering occurred in Ce-18s01, again confirming the need for at least some $\mathrm{Al}_{2} \mathrm{O}_{3}$. The volume of the cylinder of sintered sorbent removed from the reactor following Ce-18s01 was approximately $30 \%$ less than the volume of the original $\mathrm{CeO}_{2}$ charge. Concentration-time results under these conditions were meaningless.

\section{Run Ce-19}

$\mathrm{CeO}_{2}$ and $\mathrm{Al}_{2} \mathrm{O}_{3}$ were again mixed in the standard 2-to-1 ratio, and five sulfidationregeneration cycles were completed. Regeneration temperature was varied over a range of $450^{\circ} \mathrm{C}$ to $700^{\circ} \mathrm{C}$, while the chemical cleaning procedure between regeneration and sulfidation cycles was varied to obtain more information of the effect on prebreakthrough $\mathrm{H}_{2} \mathrm{~S}$ concentration. The cleaning procedures used are summarized below:

Cycle 1. $10 \% \mathrm{H}_{2} / \mathrm{N}_{2}$ was passed through the system for 3 hours with the reactor at $800^{\circ} \mathrm{C}$ and downstream tubing at $350^{\circ} \mathrm{C}$.

Cycle 2. The $\mathrm{H}_{2}$ content was increased to $20 \%$ with the cleaning time and temperature as in cycle 1.

Cycle 3. No cleaning. Run Ce-19s03 followed directly after Ce-19r02 .

Cycle 4. Air was passed through the system for about 17 hours with the reactor at $800^{\circ} \mathrm{C}$ and downstream tubing at $350^{\circ} \mathrm{C}$.

Cycle 5. The cleaning procedure was the same as in cycle 4 except that cleaning was extended over an entire weekend.

Sulfidation conditions in each cycle of Ce-19 were the same so that variations in prebreakthrough concentration should be attributed directly to the type and extent of cleaning. $\mathrm{H}_{2} \mathrm{~S}$ breakthrough results on an expanded concentration scale are shown in Figure 8. With the exception of Ce-19s05, the results were as expected based upon previous knowledge of the effect of cleaning. In Ce-19s01 and Ce-19s02, which followed $\mathrm{H}_{2}$ cleaning, the $\mathrm{H}_{2} \mathrm{~S}$ concentration gradually increased from about $0.04 \%$ ( $400 \mathrm{ppmv}$ ). Concentrations of $0.1 \%$ and $0.25 \%$ were reached in Ce-19s01 after 93 and 100 minutes, respectively; in Ce-19s02 these same concentrations were reached after 100 and 105 minutes. The cleaning step was omitted following Ce-19r02, and a large peak in $\mathrm{H}_{2} \mathrm{~S}$ concentration 


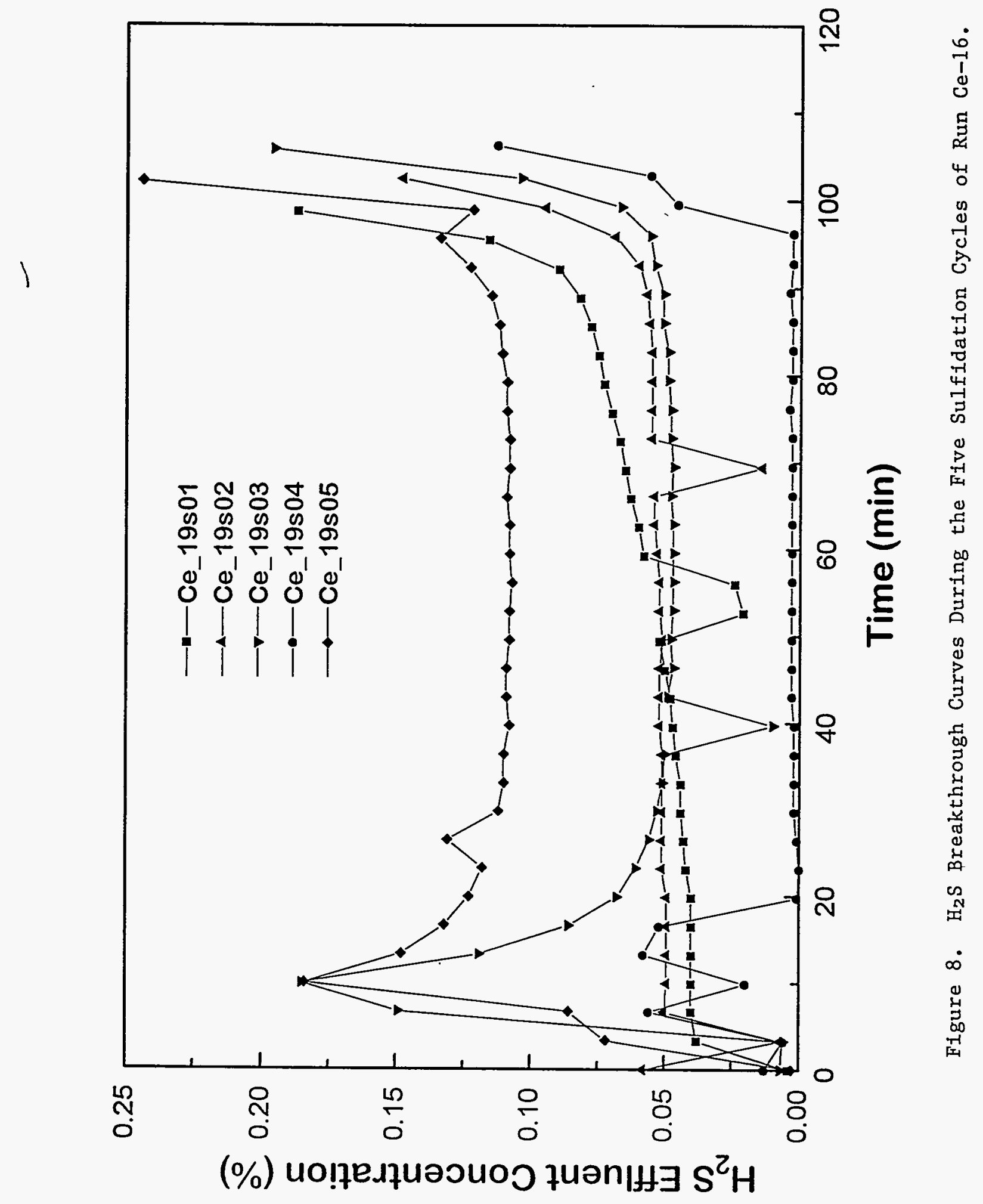


was present in Ce-19s03 after 10 minutes. The concentration then decreased to about $0.05 \%$, and concentrations of $0.1 \%$ and $0.25 \%$ occurred after 102 and 112 minutes, respectively. Thus, it appears that relatively brief ( 3 hours) cleaning in $\mathrm{H}_{2}$ is effective in eliminating the initial $\mathrm{H}_{2} \mathrm{~S}$ peak, but does not remove the more refractory sulfur responsible for the $0.04 \%$ to $0.05 \%$ prebreakthrough concentrations.

Extended air cleaning preceded Ce-19s04 and, as shown in Figure 8, following an initial $\mathrm{H}_{2} \mathrm{~S}$ peak at about $0.06 \%$ at 10 minutes, the concentration dropped to the $0.001 \%$ to $0.004 \%$ range during the 20 to 95 minute time span. This prebreakthrough result was consistent with the results from Ce-17s01 and Ce-17s02 shown previously in Figure 6. The $\mathrm{H}_{2} \mathrm{~S}$ concentration in $\mathrm{Ce}-19 \mathrm{~s} 04$ reached $0.1 \%$ after 105 minutes and $0.25 \%$ after 108 minutes, in quite good agreement with the results from Ce-19s01 through Ce-19s03.

Air at high temperature was also used to clean the system prior to Ce-19s05. The air cleaning cycle extended over an entire weekend, and we expected the Ce-19s05 sulfidation results to be as good or better than the Ce-19s04 results. However, as shown in Figure 8, this was not the case. After an initial peak near $0.2 \%$ after 10 minutes, the concentration decreased but remained above $0.1 \%$ throughout the test. There are two possible explanations for this poor performance. First, the performance is consistent with sintering which might have occurred during the prolonged high temperature cleaning. The second possibility is that the decreased reactivity was caused by the high temperature $\left(700^{\circ} \mathrm{C}\right)$ of the previous regeneration cycle, Ce-19r04.

As stated previously, each regeneration cycle of run Ce-19 was carried out at a different temperature, covering the range of 450 to $700^{\circ} \mathrm{C}$. The standard $600^{\circ} \mathrm{C}$ regeneration temperature, which had been used in all but one of the earlier tests, was omitted. This earlier test showed that regeneration was negligibly slow at $350^{\circ} \mathrm{C}$. Similarly, the regeneration rate was quite slow at the $450^{\circ} \mathrm{C}$ regeneration temperature of $\mathrm{Ce}-19 \mathrm{r} 01$. Once the fact of the slow rate was established, the temperature was increased to $600^{\circ} \mathrm{C}$ to complete the regeneration and prepare the sorbent for the next sulfidation cycle.

Regeneration was rapid and complete over the temperature range 500 to $700^{\circ} \mathrm{C}$, as shown by the $\mathrm{SO}_{2}$ breakthrough curves of Figure 9 . The effect of temperature was unexpectedly small, with the times corresponding $10 \% \mathrm{SO}_{2}$ in the product gas varying only between 20 minutes in Ce- $19 \mathrm{r} 05$ at $500^{\circ} \mathrm{C}$ and 23 minutes in Ce- $19 \mathrm{r} 04$ at $700^{\circ} \mathrm{C}$. Perhaps the most significant difference is that in the two lower temperature tests $\left(\mathrm{Ce}-19 \mathrm{r} 05\right.$ at $500^{\circ} \mathrm{C}$ and $\mathrm{Ce}-19 \mathrm{r} 02$ at $550^{\circ} \mathrm{C}$ ) the $\mathrm{SO}_{2}$ concentration in the product was significantly greater than zero by the third sample at about 6 minutes. In contrast, at the two higher temperatures (Ce$19 \mathrm{r} 03$ at $650^{\circ} \mathrm{C}$ and $\mathrm{Ce}-19 \mathrm{r} 04$ at $700^{\circ} \mathrm{C}$ ) the $\mathrm{SO}_{2}$ concentration was near zero until the fourth sample at about 10 minutes.

These results confirm that the $600^{\circ} \mathrm{C}$ standard regeneration temperature is a good choice. Significant positive or negative temperature excursions should not have a serious negative effect on the regeneration rate. 


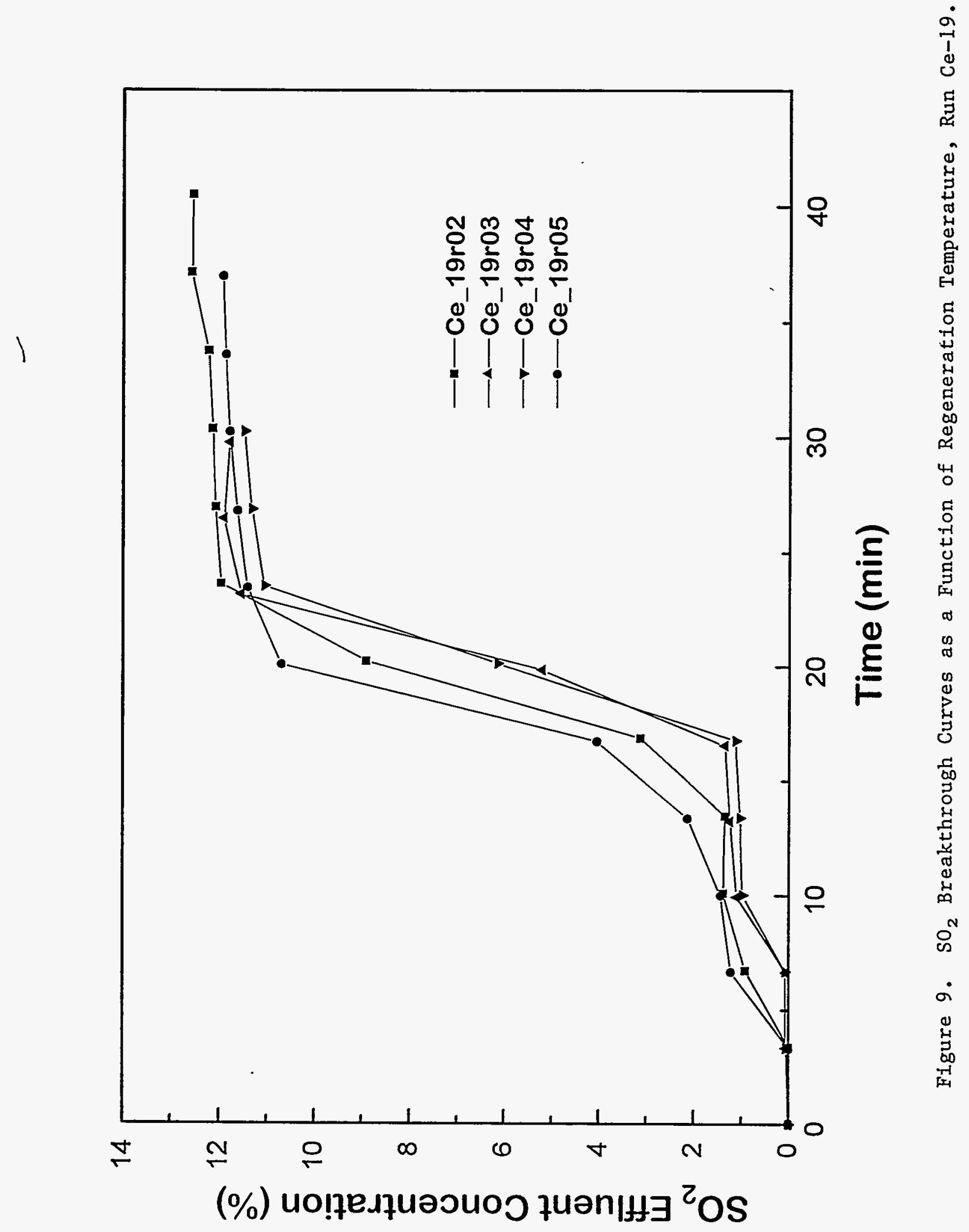




\section{$\mathrm{H}_{2} \mathrm{~S}$ REMOVAL POTENTIAL}

The possibility of the direct production of elemental sulfur during sorbent regeneration served as original justification of the cerium sorbent studies. Experimental results to date have confirmed this fact. The primary disadvantages of $\mathrm{CeO}_{2}$ compared to $\mathrm{ZnO}$ include reduced sulfur capacity and less favorable sulfidation thermodynamics. The sulfur content of $\mathrm{Ce}_{2} \mathrm{O}_{2} \mathrm{~S}$ is only $9 \mathrm{wt} \%$ compared to $33 \mathrm{wt} \%$ of $\mathrm{ZnS}$. The poorer thermodynamics led to the two-stage desulfurization concept with bulk $\mathrm{H}_{2} \mathrm{~S}$ removal using $\mathrm{CeO}_{2}$ followed by a polishing step using zinc-based sorbent. Obviously, the attractiveness of the cerium-based process would be improved if the second desulfurization stage could be eliminated. Evidence from the literature suggesting that this may, indeed, be possible has recently been found. We have begun to analyze the problem in more detail and results to date are summarized below.

Meng and Kay (1987) published results from two $\mathrm{CeO}_{2}$ sulfidation tests in which $\mathrm{H}_{2} \mathrm{~S}$ concentration was reduced from $1.2 \%(12,000 \mathrm{ppmv})$ in the feed gas to less than $10 \mathrm{ppmv}$ during a 20 minute prebreakthrough period. Sulfidation temperature was $1145 \mathrm{~K}\left(872^{\circ} \mathrm{C}\right)$ and the feed gas contained $55 \% \mathrm{CO}, 10.8 \% \mathrm{CO}_{2}, 33.0 \% \mathrm{H}_{2}$, and $1.2 \% \mathrm{H}_{2} \mathrm{~S}$. Results of these tests are reproduced as Figure 10 . The $\mathrm{CeO}_{2}$ had been pre-reduced at $1145 \mathrm{~K}$ in $5 \% \mathrm{H}_{2} / \mathrm{N}_{2}$ for 24 hours. The explanation for the low prebreakthrough $\mathrm{H}_{2} \mathrm{~S}$ concentration was that the reaction was between $\mathrm{H}_{2} \mathrm{~S}$ and reduced cerium oxide, $\mathrm{CeO}_{\mathrm{n}}(1.5<\mathrm{n}<2)$, instead of $\mathrm{CeO}_{2}$.

Bevan and Kordis (1964) published the results reproduced in Figure 11 showing the equilibrium value of $\mathrm{n}$ in $\mathrm{CeO}_{\mathrm{n}}$ as a function of temperature and oxygen pressure. Using CHEMQ, we estimate the equilibrium $\mathrm{O}_{2}$ pressure at $1145 \mathrm{~K}$ in the gas composition used by Meng and Kay to be about $3 \times 10^{-19} \mathrm{~atm}\left(1 / 2 \log \mathrm{Po}_{2}=-9.3\right)$. According to the results of Bevan and Kordis, the equilibrium composition at these conditions should be $\mathrm{CeO}_{1.93}$, which possessed more favorable thermodynamic properties than $\mathrm{CeO}_{2}$.

Results of CHEMQ calculations showing the equilibrium $\mathrm{O}_{2}$ pressure from a Shell gas as a function of temperature are summarized in Table 2 along with the estimated value of $n$ in $\mathrm{CeO}_{\mathrm{n}}$ obtained from Figure 11. A temperature slightly greater than $850^{\circ} \mathrm{C}$ would be required to achieve the same level of oxide reduction as achieved by Meng and Kay.

Thermodynamic data for reduced cerium oxide is not available, but it is reasonable to expect that the equilibrium $\mathrm{H}_{2} \mathrm{~S}$ pressure, and consequently the prebreakthrough $\mathrm{H}_{2} \mathrm{~S}$ concentration would be lower. This logic is illustrated in Figure 12 which presents the results of equilibrium calculations giving $\mathrm{H}_{2} \mathrm{~S}$ concentration as a function of temperature over $\mathrm{CeO}_{2}$ and $\mathrm{Ce}_{2} \mathrm{O}_{3}$. The extended temperature range from 300 to $1600 \mathrm{~K}$ is covered. The upper curve represents equilibrium between $\mathrm{CeO}_{2}$ and $\mathrm{H}_{2} \mathrm{~S}$ in a Shell gas of the indicated composition. This is the type of calculation that has served as the basis for evaluating the desulfurization potential of cerium-based sorbents to this point. From 300 to $800 \mathrm{~K}$, the $\mathrm{CeO}_{2-}$ $\mathrm{H}_{2} \mathrm{~S}$ reaction is exothermic and equilibrium $\mathrm{H}_{2} \mathrm{~S}$ concentration increases with increasing temperature. Above $800 \mathrm{~K}$, however, the reaction becomes endothermic and potential $\mathrm{H}_{2} \mathrm{~S}$ 


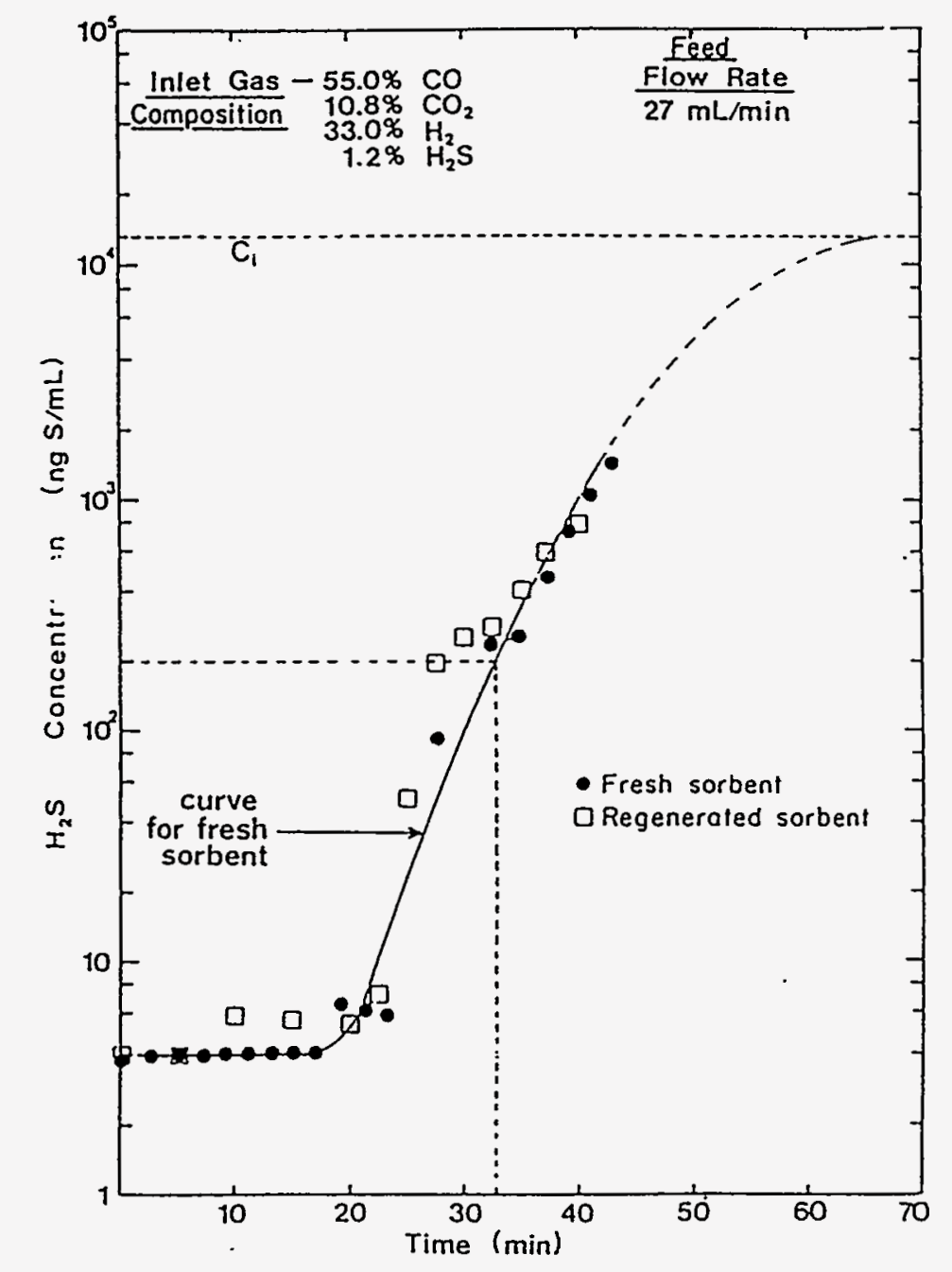

Figure 10. $\mathrm{H}_{2} \mathrm{~S}$ Breakthrough Curves During Two Sulfidation Cycles of $\mathrm{CeO}_{n} \quad(n<2)$ (Meng and Kay, 1987) 


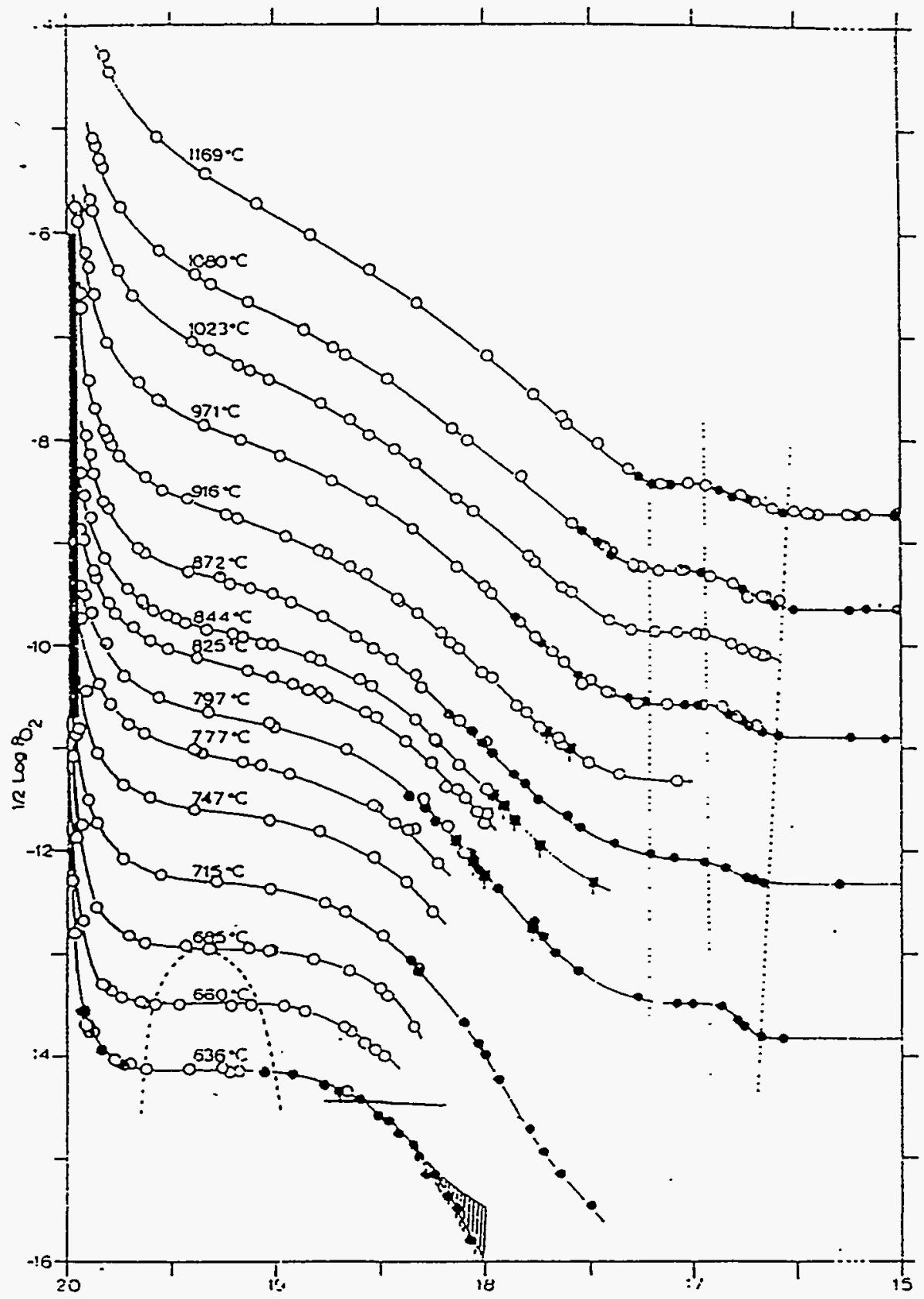

Equilibrium Value of $\mathrm{n}$ in $\mathrm{CeO}_{\mathbf{n}}$

Figure 11. Reduction of $\mathrm{CeO}_{2}$ to $\mathrm{CeO}_{n}$ as a Function of Oxygen Concentration and Temperature (Bevan and Kordis, 1964) 
Table 2. Equilibrium Oxygen Pressure and $\mathrm{CeO}_{\mathrm{n}}$ Composition in Shell Gas as a Function of Temperature.

Gas Composition, mol\%

\begin{tabular}{|c|c|c|c|c|c|c|c|}
\hline \multirow[b]{2}{*}{ Temperature, ${ }^{\circ} \mathrm{C}$} & \multirow[b]{2}{*}{700} & \multicolumn{4}{|c|}{$\begin{array}{c}\mathrm{CO}-60 . \\
\mathrm{H}_{2}-29 \\
\mathrm{CO}_{2}-2 \\
\mathrm{H}_{2} \mathrm{O}-5 \\
\mathrm{H}_{2} \mathrm{~S}-1 \\
\mathrm{~N}_{2}-3\end{array}$} & \multirow[b]{2}{*}{950} & \multirow[b]{2}{*}{1000} \\
\hline & & 750 & 800 & 850 & 900 & & \\
\hline $\mathrm{P}_{\mathrm{O} 2}$, atm. & $8 \times 10^{-23}$ & $5.4 \times 10^{-22}$ & $2.8 \times 10^{-21}$ & $3.8 \times 10^{-20}$ & $4.3 \times 10^{-19}$ & $4.0 \times 10^{-18}$ & $3.1 \times 10^{-17}$ \\
\hline $\mathrm{n}$ in $\mathrm{CeO}_{\mathrm{n}}$ & 1.99 & 1.98 & 1.97 & 1.94 & 1.89 & 1.88 & 1.85 \\
\hline
\end{tabular}




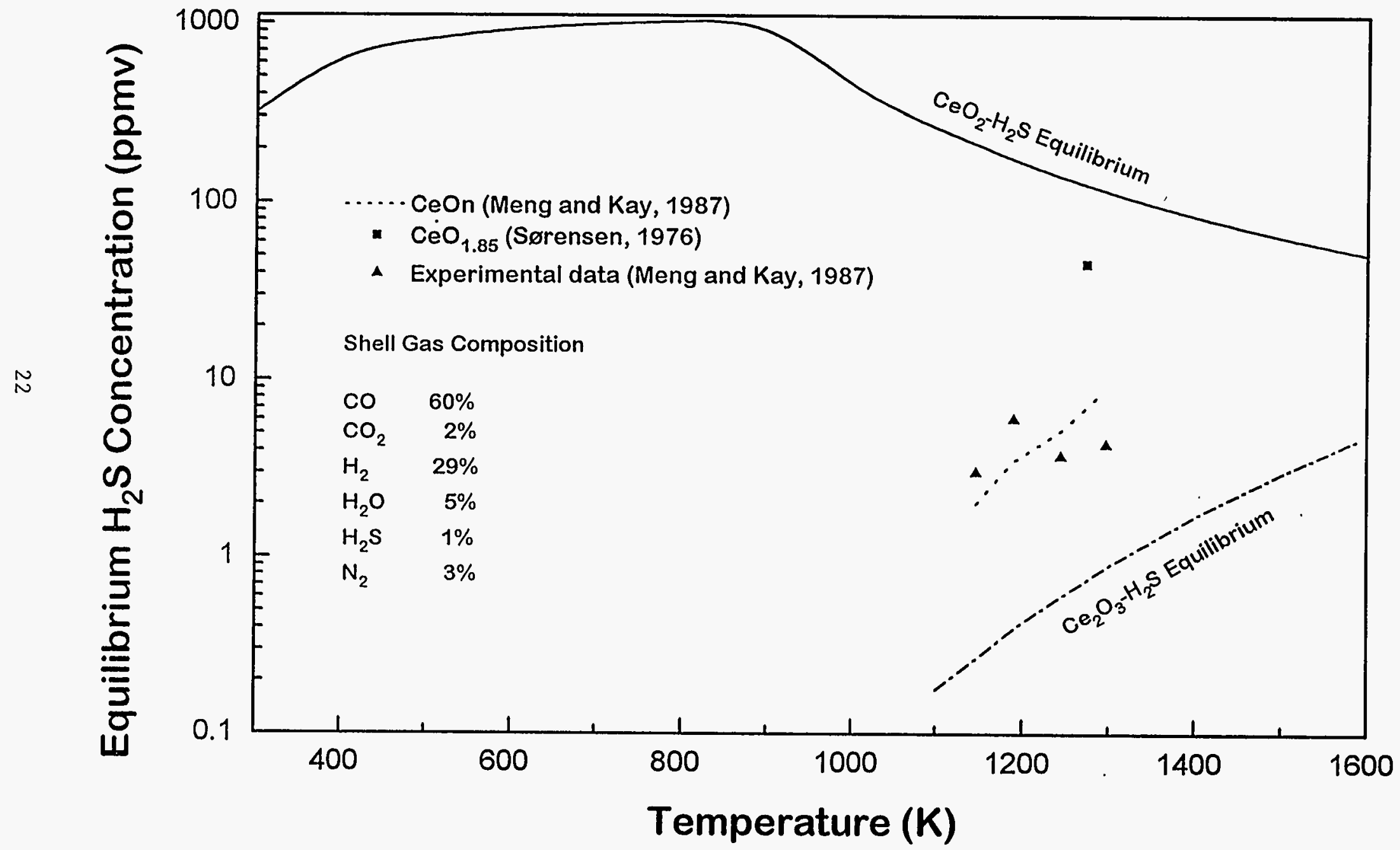

Figure 12. $\mathrm{H}_{2} \mathrm{~S}$ Equilibrium Concentration From Shell Gas in Contact with $\mathrm{CeO}_{n}$. 
removal efficiency improves with increasing temperature. At the standard experimental sulfidation temperature of $1073 \mathrm{~K}$, the equilibrium $\mathrm{H}_{2} \mathrm{~S}$ concentration is about $300 \mathrm{ppmv}$, which corresponds to the assumed $\mathrm{H}_{2} \mathrm{~S}$ concentration leaving the primary sorber in the systems analysis portion of the study. Still higher operating temperatures would improve the $\mathrm{H}_{2} \mathrm{~S}$ removal potential, but at $1600 \mathrm{~K}$ the equilibrium level of $\mathrm{H}_{2} \mathrm{~S}$ would be about 50 ppmv.

Above a certain temperature, however, the reaction would be between $\mathrm{CeO}_{n}(n<2)$ and $\mathrm{H}_{2} \mathrm{~S}$, and the equilibrium $\mathrm{H}_{2} \mathrm{~S}$ concentration would presumably be lower. The limit of improvement is shown by the lower dashed line which represents equilibrium between $\mathrm{Ce}_{2} \mathrm{O}_{3}$ $(n=1.5)$ and $\mathrm{H}_{2} \mathrm{~S}$. This reaction is exothermic throughout the temperature range and $\mathrm{H}_{2} \mathrm{~S}$ removal potential decreases with increasing temperature. However, for all temperatures below $1300 \mathrm{~K}$, the equilibrium $\mathrm{H}_{2} \mathrm{~S}$ concentration is below 1 ppmv. Even at $1600 \mathrm{~K}, \mathrm{Ce}_{2} \mathrm{O}_{3}$ is thermodynamically capable of reducing $\mathrm{H}_{2} \mathrm{~S}$ to about 5 ppmv.

The thermodynamics of $\mathrm{H}_{2} \mathrm{~S}$ removal using $\mathrm{CeO}_{\mathrm{n}}(1.5<\mathrm{n}<2.0)$ should lie between these limits. To illustrate, the intermediate dotted line between 1145 and $1296 \mathrm{~K}$ in Figure 12 represents the equilibrium $\mathrm{H}_{2} \mathrm{~S}$ concentration reported by Meng and Kay (1987), while individual points near this line represent their experimental results. Although the gas composition in Meng and Kay's study was different from the Shell gas composition, the equilibrium oxygen pressure was similar so that equilibrium $\mathrm{H}_{2} \mathrm{~S}$ concentration should also be similar. Finally, the single point at $1273 \mathrm{~K}$ and 43 ppmv $\mathrm{H}_{2} \mathrm{~S}$ was calculated using the Shell gas composition and $\mathrm{CeO}_{\mathfrak{n}}$ free energy data from Sorensen (1976), who presented data only at this temperature.

Although there is considerable uncertainty in the thermodynamics, there appears to be a reasonable chance that cerium-based sorbent could be used to reduce $\mathrm{H}_{2} \mathrm{~S}$ concentration in a single sulfidation step to the level required for IGCC operation. Two significant experimental changes will be required to test this possibility. The thermal conductivity detector (TCD) currently used for $\mathrm{H}_{2} \mathrm{~S}$ analysis must be supplemented by a flame photometric detector (FPD). The TCD is reliable only to $\mathrm{H}_{2} \mathrm{~S}$ concentrations of above $100 \mathrm{ppmv}$ while the FPD is capable of detecting $\mathrm{H}_{2} \mathrm{~S}$ to 1 ppmv or less. In addition, the reactor system downstream of the sorbent bed must be clean. As previously shown, sulfur contamination can result in apparent $\mathrm{H}_{2} \mathrm{~S}$ concentrations of $400 \mathrm{ppmv}$ or more. We hope to acquire the FPD and examine the feasibility of single-step desulfurization using cerium-based sorbents in the remaining portion of the project.

\section{PROCESS MODELING}

At the conclusion of the previous quarter, detailed process flow sheets with material and energy balances had been completed for seven design case studies. Two involved the concept of two-stage desulfurization with steam regeneration and elemental sulfur recovery using a Claus process. Four cases involved two-stage desulfurization and direct production of elemental sulfur using $\mathrm{SO}_{2}$ regeneration. In these six cases bulk $\mathrm{H}_{2} \mathrm{~S}$ removal was 
accomplished in the primary sorber using a cerium-based sorbent, and zinc-based sorbent was used for polishing in the secondary sorber. The seventh case involved single-stage desulfurization with zinc sorbent and elemental sulfur recovery using the DSRP process. Details of the assumptions involved in these cases as well as material and energy balance results were presented in the previous quarterly report.

Effort in the present quarter involved the design of major process equipment, and estimation of capital, operating, and annual levelized costs. Six of the seven case studies were included in the vessel design effort. These cases are identified in Table 3 by the nominal operating temperatures of the sorbers and regenerators. Operating temperatures for case $5 \mathrm{a}$ involving two-stage desulfurization with $\mathrm{SO}_{2}$ regeneration are effectively equal to the temperatures being used in the experimental study, while temperatures for case 6 involving single-stage desulfurization with DSRP are taken from values reported by Research Triangle Institute. Operating temperatures for other cases are arbitrarily selected to permit the effect of operating conditions on process cost to be estimated.

A list of major equipment, equipment sizes, and estimated purchased equipment cost is presented in Tables 4, 5 and 6 for the two cases of two-stage desulfurization with steam regeneration, three cases of two-stage desulfurization with $\mathrm{SO}_{2}$ regeneration, and single case of single-stage desulfurization with DSRP, respectively. Sizes of each equipment type are expressed in the units required by the sources of the cost estimation data. All costs are expressed in 1996 dollars and the Chemical Engineering Plant Cost Index has been used to update earlier cost data to the 1996 level.

The following material describes the basis used for the design and costing of each major equipment type.

\section{Reactors}

Four primary reactor vessels are required for all two-stage desulfurization cases while only three are needed for single-stage desulfurization with DSRP. All four vessels required for two-stage desulfurization with steam regeneration are assumed to be adiabatic bubbling fluidized beds. While all four vessels required for two-stage desulfurization with $\mathrm{SO}_{2}$ regeneration are bubbling fluidized beds, only the primary and secondary sorbers and secondary regenerator operate adiabatically. Nonadiabatic operation of the primary regenerator is required because of the highly exothermic nature of the reaction between $\mathrm{Ce}_{2} \mathrm{O}_{2} \mathrm{~S}$ and $\mathrm{SO}_{2}$. The $\mathrm{SO}_{2}$ recycle rate was fixed to simultaneously satisfy the heat transfer and fluidization velocity requirements. The single sorber and regenerator used in the singlestage desulfurization with DSRP option were designed on the basis of adiabatic bubbling fluidized beds, while the DSRP reactor is a nonadiabatic fixed-bed. Energy liberated by the exothermic DSRP reaction is too large to permit adiabatic operation.

The fluidized beds were sized following the procedure described by Chen et al. (1992). Superficial gas velocity was set at $1 \mathrm{ft} / \mathrm{s}$ which is approximately 5 to 7 times the 
Table 3. Identification of the Six Case Studies by the Operating Temperature of the Reactors.

Two-Stage Desulfurization With Steam Regeneration

Case

Reactor

Primary Sorber

Secondary Sorber

Primary Regenerator 1

Secondary Regenerator
Type

Adiabatic Fluidized Bed

Adiabatic Fluidized Bed

Adiabatic Fluidized Bed

Adiabatic Fluidized Bed
Nominal Temperature, $\mathrm{K}$

1

2

1000

873

1000

1000
900

873

900

1000

Two-Stage Desulfurization With $\mathrm{SO}_{2}$ Regeneration

Case

$3 a$

$4 a$

$5 a$

Reactor

Primary Sorber

Secondary Sorber

Adiabatic Fluidized Bed

Adiabatic Fluidized Bed

1000

900

1073

Nonadiabatic Fluidized Bed

873

1000

873

873

Adiabatic Fluidized Bed

1000

900

873

Secondary Regenerator

\begin{abstract}
Adiabatic Fluidized Bed
\end{abstract}
Single-Stage Desulfurization With DSRP

Case

Reactor

Sorber

Regenerator

Adiabatic Fluidized Bed

873

Adiabatic Fluidized Bed

1000

DSRP

Nonadiabatic Fixed Bed

873 
Table 4. Major Equipment List and Estimated Purchased Cost for

Two-Stage Desulfurization with Steam Regeneration Cases.

Case 1

1000K Primary Sorber

Equipment Size Purchased Cost Equipment Size Purchased Cost (various units) $\quad\left(10^{6} \$, 1996\right)$
Case 2

900K Primary Sorber (various units)

$\left(10^{6} \$, 1996\right)$

Reactor Vessels (vessel weight, lb)

Primary Sorber

Secondary Sorber

Primary Regenerator

Secondary Regenerator

Refractory

Subtotal

Heat Exchangers

Waste Heat Boilers (lb steam $/ \mathrm{hr}$ )

H3
H13
H12
H15
H16
H17

Shell and Tube $\left(\mathrm{ft}^{2}\right)$

$\mathrm{H} 1$

Subtotal

Pump

Flow Rate (gpm)

Head (ft)

Steam Drum (gal)

Sour Water Stripper

Diameter $(\mathrm{ft})$

Height (ft)

Pressure Swing Adsorption

Flow Rate $(\mathrm{lbmol} / \mathrm{hr})$

Claus Unit and Tail Gas Unit

( $\mathrm{S}$ intake, (ton/day)

Total
$3.81 \times 10^{4}$

$3.32 \times 10^{4}$

$3.73 \times 10^{3}$

$2.40 \times 10^{3}$

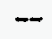

$-$

0.87

0.36

0.33

0.08

0.06

0.04
$3.42 \times 10^{4}$

$3.32 \times 10^{4}$

$3.35 \times 10^{3}$

$3.40 \times 10^{3}$

--

0.34

0.33

0.07

0.07

0.04

0.86
0.03

0.17

0.12

0.13

36,000

450

0.01

0.46

0.04

1600

0.02

2.4

48

320

56

$-$

1.38
190

2900

1500

0.02

0.13

0.10

0.07

68,000

0.19

0.01

0.50

0.04

2.4

48

310

53

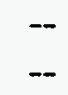

1.41 
Table 5. Major Equipment List and Estimated Purchased Cost for Two-Stage Desulfurization With $\mathrm{SO}_{2}$ Regeneration Cases.

\section{Case 3a}

1000K Primary Sorber

Equipment Size Purchased Cost (various units)
Case $4 a$

900K Primary Sorber
Case 5a

1073K Primary Sorber

\section{Reactor Vessels (vessel weight, lb) \\ Primary Sorber \\ Secondary Sorber \\ Primary Regenerator \\ Secondary Regnerator \\ Refractory}

\section{Subtotal}

Heat Exchanger

Waste Heat Boilers (lb steam $/ \mathrm{hr}$ )

$$
\begin{aligned}
& \text { H12 } \\
& \text { H15 } \\
& \text { H16 }
\end{aligned}
$$

Shell and tube $\left(\mathrm{ft}^{2}\right)$

$\mathrm{H} 1$

\section{Subtotal}

Compressor (hp)

Pump

Flow Rate (gpm)

Head ( $\mathrm{ft}$ )

Steam Drum (gal)

$\begin{array}{cc}3.81 \times 10^{4} & 0.36 \\ 3.32 \times 10^{4} & 0.33 \\ 3.98 \times 10^{3} & 0.08 \\ 2.4 \times 10^{3} & 0.06 \\ -- & 0.04 \\ -. & 0.87\end{array}$

64,000

9,900

24,700

1330

103

250

2,930

3,000

0.06

0.36

0.04 $\left(10^{6} \$, 1996\right)$

Equipment Size (various units)
Purchased Cost $\left(10^{6} \$, 1996\right)$

Equipment Size Purchased Cost (various units)

$\left(10^{6} \$, 1996\right)$

$\begin{array}{cccc}3.42 \times 10^{4} & 0.34 & 4.09 \times 10^{4} & 0.38 \\ 3.33 \times 10^{4} & 0.33 & 3.32 \times 10^{4} & 0.33 \\ 3.98 \times 10^{3} & 0.08 & 3.98 \times 10^{3} & 0.08 \\ 3.44 \times 10^{3} & 0.07 & 2.08 \times 10^{3} & 0.05 \\ -- & 0.04 & -- & 0.04 \\ -- & 0.86 & -- & 0.88\end{array}$

0.38

0.33

0.05

0.88

86,400

0.21

17,500

0.08

3,100

0.03

52,300

0.16

7,630

0.05

36,200

0.13

1,250

0.02

1,530

0.02

0.34

0.36

106

0.04

118

0.04

250

0.05

240

2,930

0.05

2,900

0.02

2,800

0.02

1.30 
Table 6. Major Equipment List and Estimated Purchased Cost for Single-Stage Desulfurization With DSRP.

Case 6

Equipment Size (various units)
Purchased Cost $\left(10^{6} \$, 1996\right)$

Reactor Vessels (vessel weight, lb)

Sorber

Regenerator

DSRP Reactor

Refractory

Subtotal

Heat Exchangers

Waste Heat Boilers (lb steam $/ \mathrm{hr}$ )

$\mathrm{H} 2$

$\mathrm{H} 4$

$\mathrm{H} 1$

Shell and Tube ( $\left.\mathrm{ft}^{2}\right)$

H8

H3

H9
$3.23 \times 10^{4}$

$2.20 \times 10^{4}$

$1.67 \times 10^{4}$
0.32

0.25

0.21

0.05

0.83
15,000

31,500

62,400

1,200

3,600

14,700
0.08

0.12

0.18

0.02

0.04

0.21

0.65

2,800

0.98

390

0.15

Recycle

Pump

Flow Rate (gpm)

Head (ft)

Steam Drum (gal)

270

2,930

3400
0.05

0.02

2.67 
minimum fluidization velocity. Contact time in the fluidized bed was fixed at $6 \mathrm{~s}$ which corresponds to a bed height of $6 \mathrm{ft}$. $50 \%$ freeboard height was added so that all fluidized-bed reactors are $9 \mathrm{ft}$ in height. Six inches of refractory was included in each reactor because of the high operating temperature. An approximate heat transfer calculation was used to estimate the shell temperature, and shell thickness was determined in accordance with ASME codes as described by Peters and Timmerhaus (1991).

The volume of the fixed-bed reactor was determined from the space velocity of $4560 \mathrm{hr}^{-1}$ (STP) specified by Gangwal et al. (1993). This volume was then distributed appropriately between diameter and height. Six inches of refractory lining was added and the shell thickness was calculated in the manner described above.

Internal heat transfer for the DSRP reactor and the primary regenerator in the $\mathrm{SO}_{2}$ regeneration cases was based on $11 / 4$ inch OD heat transfer tubes. The overall heat transfer coefficient of $\mathrm{U}=30 \mathrm{Btu} / \mathrm{hrft}^{2 \circ} \mathrm{F}$ was based on literature values reported by Seko et al. (1983), Piepers et al. (1983), and Donsi et al. (1983).

Reactor vessel dimensions are presented in Table 7. The height of all fluidized-bed reactors is $9 \mathrm{ft}$ while the fixed-bed DSRP reactor is $11.5 \mathrm{ft}$ in height. The open vessel diameter is the inside diameter to the beginning of the refractory lining. Six inches of refractory adds 1 foot to the metal wall inside diameter, and the outside diameter of the pressure vessel is equal to the inside metal wall diameter plus two times the wall thickness. Heat transfer tubes are included only in the nonadiabatic reactors.

All sorbers are approximately the same size. The difference in open vessel diameters, which ranges from $7.9 \mathrm{ft}$ to $8.8 \mathrm{ft}$ is due primarily to different operating temperatures. The smaller open vessel diameter of the sorber used in single-stage desulfurization with DSRP is also due partially to the diversion of a small amount of coal gas to the DSRP reactor. Regenerators are smaller, with diameters ranging from $1.6 \mathrm{ft}$ to $6.5 \mathrm{ft}$. These differences are due to both gas flow rate and temperature, with the flow rate to the regenerator used in single-stage desulfurization with DSRP significantly larger because of the large nitrogen diluent flow. The DSRP reactor is of intermediate diameter, but is somewhat higher than the fluidized-bed reactors.

The purchased cost of individual reactors was estimated from an equation in Peters and Timmerhaus (1991) based on the vessel weight

$$
\mathrm{K}=80 \mathrm{w}^{0.66}
$$

$\mathrm{K}$ is the vessel cost in 1990 dollars with a cost index of 356 and $\mathrm{W}$ is the vessel mass in $\mathrm{lb}_{\mathrm{m}}$. The cost entries in Tables 4, 5, and 6 represent the total cost of the four parallel reaction trains. Cost of refractory lining in each reactor is based on an informal estimate from a vendor (Milton, 1996). Note that the total purchased cost of the reactor vessels varies only 
Table 7. Reactor Sizes for the Six Case Studies.

$\begin{array}{clccc}\begin{array}{c}\text { Height } \\ (\mathrm{ft})\end{array} & \text { Open Vessel } & \text { Metal Wall } & \text { Metal Wall } & \text { No. of Heat } \\ & \text { Diameter (ft) } & \text { Inside } & \text { Thickness } & \text { Transfer } \\ & & \text { Diameter (ft) } & & \text { Tubes }\end{array}$

Case 1 - Two-Stage Desulfurization with $\mathrm{H}_{2} \mathrm{O}$ Regeneration

Primary Sorber (adiabatic)

9

Secondary Sorber (adiabatic)

9

Primary Regenerator (adiabatic)

Secondary Regenerator (adiabatic)

9

Case 2 - Two-Stage Desulfurization with $\mathrm{H}_{2} \mathrm{O}$ Regeneration

Primary Sorber (adiabatic)

Secondary Sorber (adiabatic)

Primary Regenerator (adiabatic)

Secondary Regenerator (adiabatic)

9

9

9

9

Case 3a - Two-Stage Desulfurization with $\mathrm{SO}_{2}$ Regeneration

Primary Sorber (adiabatic)

Secondary Sorber (adiabatic)

Primary Regenerator (nonadiabatic)

Secondary Regenerator (adiabatic)

Case 4a - Two-Stage Desulfurization with $\mathrm{SO}_{2}$ Regeneration

Primary Sorber (adiabatic)

Secondary Sorber (adiabatic)

Primary Regenerator (nonadiabatic)

Secondary Regenerator (adiabatic)

Case 5a - Two-Stage Desulfurization with $\mathrm{SO}_{2}$ Regeneration

Primary Sorber (adiabatic)

Secondary Sorber (adiabatic)

Primary Regenerator (nonadiabatic)

Secondary Regenerator (adiabatic)

Case 6 - Single-Stage Desulfurization with DSRP

Sorber (adiabatic)

Regenerator (adiabatic)

DSRP Reactor (nonadiabatic)
8.5

9.5

2.0

1.9

0.8

3.2

2.2

2.6

0.6

8.1

8

9.1

2.0

2.1

3.0

3.1

1.9

1.9

0.7

0.7

0

0

0

0

0

0

0

0
9

9

9

9

8.5

8

2.3

1.6

2.0

1.9

0.8

0.6

\section{3}

2.6

8.1

8

2.3

2.1

9.1

9

3.3

3.1

1.9

1.9

0.8

0.7

\section{0}

(18

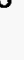


between $\$ 0.83$ million (case 6 ) and $\$ 0.88$ million (case $5 a$ ), and that the reactor costs are only weak functions of operating conditions. Only three primary reaction vessels are required for single-stage desulfurization with DSRP (case 6) compared to four vessels in all two-stage desulfurization options (cases 1 through 5a). However, all three vessels in case 6 are large while primary regenerators in cases 1 through $5 \mathrm{a}$ are much smaller. Thus, the final costs are relatively equal.

\section{Heat Exchangers/Waste Heat Boilers}

Four waste heat boilers and one shell-and-tube heat exchanger are required for each of the two-stage desulfurization with steam regeneration cases. Three waste heat boilers and one shell-and-tube exchanger are required for two-stage desulfurization with $\mathrm{SO}_{2}$ regeneration, and three waste heat boilers and three shell-and-tube exchangers are needed for single-stage desulfurization with DSRP. The waste heat boilers include the units which are integral to the primary regenerators in the two-stage desulfurization with $\mathrm{SO}_{2}$ regeneration cases and the DSRP reactor in the single-stage regeneration with DSRP option.

The size of the waste heat boilers was based on the pounds per hour of steam generated, numbers obtained directly from the PRO/II energy balance. An informal vendor quote (Willis, 1996) provided a purchased cost of $\$ 75,000$ for a unit having a capacity of $15,000 \mathrm{lb} / \mathrm{hr}$ of steam. The " 0.6 factor rule" was used to estimate the cost for other capacities.

For all shell-and-tube heat exchangers, the values of $U A\left(B t u / h r^{\circ} \mathrm{F}\right)$ came directly from the PRO/II energy balance. Exchanger area was then determined after estimating the heat transfer coefficient, U. Exchangers $\mathrm{H} 1$ in cases 1 through 5a and exchanger $\mathrm{H} 9$ in case 6 are the elemental sulfur condensers. The heat transfer coefficients, estimated from Kern (1950) depend on the quantity of noncondensables in the feed gas. The estimated coefficients ranged from $30 \mathrm{Btu} / \mathrm{hrft}^{2 \circ} \mathrm{F}$ for case 6 where $95 \%$ of the feed gas is noncondensable to 180 $\mathrm{Btu} / \mathrm{hrft}{ }^{2 \circ} \mathrm{F}$ in cases 1 and 2 where only $30 \%$ of the feed gas is noncondensable. Exchanger costs were estimated from a correlation in Peters and Timmerhaus (1991) and updated to 1996 levels using the Chemical Engineering Cost Index.

The combined cost of waste heat boilers and heat exchangers was only weakly dependent on operating conditions. For example, the purchased cost for the three two-stage desulfurization with $\mathrm{SO}_{2}$ regeneration cases varied only between $\$ 0.34$ million and $\$ 0.36$ million (Table 5). This option resulted in the lowest cost while the highest cost was associated with the single-stage desulfurization with DSRP with an estimated cost of $\$ 0.64$ million (Table 6).

\section{Compressors and Pumps}

Compressor and pump horsepower requirements were obtained directly from the $\mathrm{PRO} / \mathrm{II}$ simulation and were based on efficiencies of 0.85 and 0.65 for the compressors and 
pumps, respectively. All cases require a large boiler feed water pump with the power depending upon the amount of steam generated. No compressors are required by the twostage desulfurization with steam regeneration options, while a $\mathrm{SO}_{2}$ recycle compressor is required for the two-stage desulfurization with $\mathrm{SO}_{2}$ regeneration cases. The single-stage desulfurization with DSRP requires a recycle compressor and a large three-stage air compressor. The air compressor is primarily responsible for the higher cost for pumps and compressors associated with the single-stage desulfurization with DSRP option.

Compressor cost estimates were based directly on horsepower using information from Peters and Timmerhaus (1991). The pump cost data was obtained from Kirk-Othmer (1976) based on a combination of feed water flow rate and pump head.

\section{Steam Drum}

The steam drum is a minor cost item common to all cases. Although the design volume of the steam drum was somewhat variable, the estimated purchased cost rounded off to $\$ 0.02$ million in all cases.

Note that no purchased equipment costs are included in Table 4 (two-stage desulfurization with steam regeneration) for the sour water stripper, pressure swing absorber, and Claus and tail gas units. The estimate of their cost is introduced at the total process capital requiremental level which is presented subsequently.

Comparison of the total purchased equipment cost estimates from Tables 4, 5, and 6, shows little dependence on operating conditions for any of the two-stage desulfurization with steam or $\mathrm{SO}_{2}$ regeneration options. However, as previously noted, major equipment items have been omitted from the steam regeneration cases. The purchased equipment cost estimate for single-stage desulfurization with DSRP is approximately twice as large as the equivalent cost for either of the two-stage desulfurization with $\mathrm{SO}_{2}$ regeneration options. The three-stage air compressor is responsible for most of this difference.

\section{Total Capital Requirement}

The total capital requirement includes such items as construction expenses, engineering fees, and working capital as listed in Table 8. The estimated cost of individual items is based on the indicated percent of the purchased equipment cost. The percentage of all items contributing to the process capital subtotal is taken from Peters and Timmerhaus (1991) while the percentage of all items below the process capital is taken from Buchanan et al. (1994). As shown in Table 8, the estimated total capital requirement for case studies 3a through 6 is 4.93 times the purchased equipment cost. The total capital investment for cases 1 and 2 involving two-stage desulfurization with steam regeneration is even larger because the estimated cost of the sour water stripper, pressure swing absorber, Claus unit, and tail gas unit were included at this stage. With the additional units, the total capital requirement, 
Table 8. Total Capital Estimation Basis

Direct Cost

Purchased Equipment

Purchased Equipment Installation

Instrumentation and Controls

Piping (Installed)

Electrical (Installed)

Buildings (Including services)

Yard Improvements

Service Facilities

Land

1

Indirect Cost

Construction Expensess

Process Capital Total

Engineering Fees

Process Contingency

Project Contingency

Total Plant Cost

AFDC Cost

Total Plant Investment

Prepaid Royalties

Initial Catalysts

Startup Costs

Spare parts

Working Capital

Land

Total Capital Investment
$\%$ of Purchased Equipment

100

39

13

31

10

29

10

55

6

Subtotal

293

34

327

33

26

49

435

28

463

2

1

13

2

10

2

493 
as shown in Table 9, for two-stage desulfurization with steam regeneration is by far the largest, followed by single-stage desulfurization with DSRP, and leaving two-stage desulfurization with $\mathrm{SO}_{2}$ regeneration with the smallest capital requirement.

Two previous economic studies, by McMichael and Gangwal (1991) and by Buchanan et al. (1994), have also considered the cost of the single-stage desulfurization with DSRP option. Direct comparison of the results is not possible because of the different time periods, plant sizes, and operating conditions. McMichael and Gangwal (1991) considered only the cost of sulfur recovery using DSRP (not including desulfurization and regeneration costs) for a plant having a coal gas feed rate about one-half the rate used in the current study and a pressure of $20 \mathrm{~atm}$ compared to $25 \mathrm{~atm}$ in the current study. Their estimate of the process capital requirement was $\$ 2.15$ million on a 1987 basis. Buchanan et al (1994) evaluated the cost of an entire IGCC plant having the same coal gas feed rate as the present study, but also at a lower operating pressure of $20 \mathrm{~atm}$. Fortunately, Buchanan et al. reported capital costs of individual sections of the IGCC plant. On a 1993 basis, their estimate of the process capital required for the desulfurization, regeneration, and sulfur recovery portions was $\$ 7.16$ million. The process capital required for the combined desulfurization and regeneration sections was $\$ 3.3$ million compared to $\$ 3.85$ million for sulfur recovery.

We have used the above information and made approximate corrections to compare the capital requirements from the three studies on a common basis of $17,000 \mathrm{lbmol} / \mathrm{hr}$ of coal gas feed, an operating pressure of $20 \mathrm{~atm}$, and using 1996 dollars. The only correction needed for the LSU study was to reduce the pressure from 25 atm to 20 atm. The resulting process capital estimate was reduced from $\$ 8.8$ million to $\$ 8.5$ million. The original process capital estimate of Buchanan et al. (1994) was increased from $\$ 7.15$ million to $\$ 7.6$ million in updating their costs to 1996 dollars. Several adjustments were required to bring the McMichael and Gangwal (1991) study to the common basis. First, their estimate of $\$ 2.15$ million in 1987 dollars for sulfur recovery only was increased to $\$ 4.0$ million to include the desulfurization and regeneration sections as well. This adjustment was made using the ratio of process capital for desulfurization and regeneration compared to sulfur recovery $(3.85 / 3.3=1.17)$ reported by Buchanan et al. (1994). Next, the 0.6 factor was applied to increase the coal gas throughout to the common $17,000 \mathrm{lbmol} / \mathrm{hr}$ basis. Finally the costs were updated to 1996 using the appropriate cost indices. The final process capital estimate was $\$ 7.4$ million.

Although the methods are very approximate, the resultant process capital estimates from the three studies are reasonably close, ranging from $\$ 7.4$ million (McMichael and Gangwal) to $\$ 7.6$ million (Buchanan et al.) to $\$ 8.5$ million in this study. For practical purposes these estimates may be considered as being equal since the uncertainty in the estimate is larger than the minimum to maximum variation.

\section{Operating Cost}

At this stage the number of case studies was reduced to two -- one involving twostage desulfurization with $\mathrm{SO}_{2}$ regeneration (case 5a) and the other involving single-stage 
Table 9. Summary of the Total Capital Investment for the Six Case Studies

Case

1.

2.

3a.

4a.

$5 a$.

6.
Description

Two-Stage Desulfurization, Steam Regeneration, $1000 \mathrm{~K}$ Primary Sorber

Two-Stage Desulfurization, Steam Regeneration, 900K Primary Sorber

Two-Stage Desulfurization, $\mathrm{SO}_{2}$ Regeneration, $1000 \mathrm{~K}$

Primary Sorber

Two-Stage Desulfurization, $\mathrm{SO}_{2}$ Regeneration, $900 \mathrm{~K}$

Primary Sorber

Two Stage Desulfurization, $\mathrm{SO}_{2}$ Regeneration, $1073 \mathrm{~K}$

Primary Sorber

Single-Stage Desulfurization, DSRP
Total Capital Requirement $\left(10^{6} \$, 1996\right)$

21.43

21.58

6.55

6.45

6.65

13.2 
desulfurization with DSRP (case 6) -- for the purposes of operating cost estimation. Further consideration of two-stage desulfurization with steam regeneration was dropped when it became obvious that this concept would not be economically attractive. The capital requirement was significantly greater, the process was more complex, and the sorbent replacement rate, which (as will be shown) is the major operating cost, was comparable to the less capital intensive and simpler two-stage desulfurization with $\mathrm{SO}_{2}$ regeneration option. In addition, operating cost estimates were carried out for only one (case 5a) of the three twostage desulfurization with $\mathrm{SO}_{2}$ regeneration options when it became obvious that capital and operating costs were relatively weak functions of the temperatures of the primary sorber and regenerator.

The key factors in estimating operating costs are consumption or generation rates of raw materials, by-products and utilities coupled with the unit costs of these items. Consumption and generation rates were obtained directly from the PRO/II simulation and are summarized in Table 10. Unit costs for these materials are presented in Table 11. Column 1 identifies the cost (or credit) item. Columns 2, 3, and 4 present the unit cost, the date of the unit cost, and the source of the unit cost data. Finally, the numbers in column 5 represent the unit costs updated to 1996. For example, the unit cost for zinc titanate sorbent of $\$ 7000 /$ ton in 1993 was taken from Buchanan et al. (1994), and the estimate of $\$ 7500 /$ ton in 1996 was obtained from the ratio of the cost indices. The unit costs of other items, with the exception of the DSRP catalyst, were estimated in the same manner. The annual cost of DSRP catalyst was taken directly from Buchanan et al. (1994) and updated to 1996 using cost factors.

Annual operating costs (credits) for raw materials, by-products, and utilities are summarized in Table 12. The values represent the product of the unit costs (Table 11) and the annual consumption (production) rate (Table 10). The annual cost of raw materials, byproducts, and utilities for the two-stage desulfurization with $\mathrm{SO}_{2}$ regeneration option (case 5a) is about twice that of the single-stage desulfurization with DSRP case (case 6), and almost all of the additional cost is directly attributable to the cost of the cerium sorbent compared to the zinc sorbent.

Also included in operating costs are such items as operating labor, maintenance labor, administration and support labor. These costs, designated as fixed operating costs, were estimated to be $5.45 \%$ of the process capital requirement following McMichael and Gangwal (1991), and are shown near the bottom of Table 12.

\section{Levelized Cost}

Final cost comparisons are based on the annual levelized cost (Electric Power Research Institute, 1982) which permits comparison of competing cases using single numbers in contrast with a display of full cash flow or present worth. Levelization of the operating costs is achieved by multiplying the first year's operating cost by a factor $L_{\mathfrak{n}}$ which 
Table 10. Consumption and Production Rates of Raw Materials, By-Products and Utilities.
Two-Stage Desulfurization With $\mathrm{SO}_{2}$ Regeneration
(Case 5a)
Single-Stage Desulfurization with DSRP
(Case 6)

Raw Materials

Zinc Sorbent

$0.08 \mathrm{lbmol} / \mathrm{hr}$

$1.68 \mathrm{lbmol} / \mathrm{hr}$

Cerium Sorbent

$6.88 \mathrm{lbmol} / \mathrm{hr}$

Coal Gas

$-$

-

$177 \mathrm{lbmol} / \mathrm{hr}$

By-Products

Sulfur

Steam

$164 \mathrm{lbmol} / \mathrm{hr}$

$171 \mathrm{lbmol} / \mathrm{hr}$

$6050 \mathrm{lbmol} / \mathrm{hr}$

$7560 \mathrm{lbmol} / \mathrm{hr}$

Utilities

Boiler Feed Water

Electricity

$6480 \mathrm{lbmol} / \mathrm{hr}$

$384 \mathrm{hp}$
$7560 \mathrm{lbmol} / \mathrm{hr}$

$3540 \mathrm{hp}$ 
Table 11. Base Unit Cost of Raw Materials, By-Products and Utilities.

Raw Materials

Zinc Sorbet

Cerium Sorbent

DSRP Catalyst

Coal Gas

1

Nitrogen

Oxygen

By-Products

Sulfur

Steam
Unit Cost Date Reference

$\$ 7,000 /$ ton 1993 Buchanan et al. (1994)

$\$ 6,400 /$ ton 1996 Stanford Materials (1997)

$\$ 4,000 / y r \quad 1996$ Buchanan et al. (1994)

$\$ 1.07 / 1 \mathrm{bmol}$

$\$ 25 /$ ton

$\$ 40 /$ ton

1996 Cammarnata (1997)

1996

1987

McMichael and Gangwal (1991)

Cammarnata (1997)
1996

Unit Cost

$\$ 7,500 /$ ton

$\$ 6,400 /$ ton

$\$ 4,250 /$ ton

$\$ 1.25 / \mathrm{lbmol}$

$\$ 25 /$ ton

$\$ 40 /$ ton

$\$ 90 /$ ton (1987)

$\$ 4.9 / 1000 \mathrm{lb} \quad 1981 \quad$ EPRI (1982)

\section{Utilities}

Boiler Feed Water $\quad \$ 11.2 / 1000$ gal 1987 McMichael and Gangwal $\quad \$ 13.2 / 1000$ gal (1991)

Electricity

\$0.059/kwh 1987 McMichael and Gangwal (1991)

$\$ 0.07 / \mathrm{kwh}$ 
Table 12. Annual Variable and Fixed Operating Cost (Credit) $\left(10^{6} \$, 65 \%\right.$ Capacity Factor $)$.

\begin{tabular}{|c|c|c|}
\hline & $\begin{array}{l}\text { Two-Stage Desulfurization } \\
\text { With } \mathrm{SO}_{2} \text { Regeneration } \\
\text { (Case 5a). }\end{array}$ & $\begin{array}{l}\text { Single-Stage Desulfurization } \\
\text { With DSRP } \\
\text { (Case 6) }\end{array}$ \\
\hline \multicolumn{3}{|l|}{ Raw Materials } \\
\hline Zinc Sorbent & 0.41 & 8.62 \\
\hline Cerium Sorbent & 21.42 & -- \\
\hline Coal Gas & - & 3.11 \\
\hline Nitrogen & - & 2.20 \\
\hline Oxygen & 0.65 & -- \\
\hline \multicolumn{3}{|l|}{ By-Products } \\
\hline Sulfur & $(1.34)$ & $(1.41)$ \\
\hline Steam & $(3.91)$ & $(4.88)$ \\
\hline \multicolumn{3}{|l|}{ Utilities } \\
\hline Boiler Feed Water & 1.05 & 1.23 \\
\hline Electricity & 0.11 & 1.05 \\
\hline Total Variable Operating Costs & 18.39 & 9.92 \\
\hline Fixed Operating Cost & 0.24 & 0.48 \\
\hline
\end{tabular}


distributes the sum of the present worth of all future operating costs equally over the lifetime of the project. Levelization of capital costs over the lifetime of the project is achieved by multiplying the capital costs by the factor $\mathrm{P}_{\mathrm{n}}$. For an annual escalation factor of $6 \%$ and a ten-year analysis period, the values of $L_{10}$ and $P_{10}$ are 1.321 and 0.195 (O'Hara et al., 1987), respectively.

Final annual levelized costs for the two cases are compared in Table 13, along with the percent contribution to the total cost of each item. Two-stage desulfurization with $\mathrm{SO}_{2}$ regeneration (case $5 \mathrm{a}$ ) is shown to be almost $60 \%$ more expensive, with an annual total levelized cost of $\$ 25.9$ million compared to $\$ 16.3$ million for single-stage desulfurization with DSRP. Sorbent replacement is the dominant cost item in both cases. Cerium sorbent replacement cost alone is greater than the total cost of case $5 \mathrm{a}$ since credits for steam and sulfur exceed the cost of all other items.

Other items contributing significantly to the cost of two-stage desulfurization with $\mathrm{SO}_{2}$ regeneration (case $5 \mathrm{a}$ ) include boiler feed water $(5.4 \%)$, fixed cost $(5.1 \%)$, oxygen $(3.3 \%)$, and zinc sorbent $(2.1 \%)$. The credits for steam (20\%) and sulfur $(6.8 \%)$ more than offset the costs of other items. Other items contributing significantly to single-stage desulfurization with DSRP include coal gas (25.2\%), nitrogen (17.8\%) and fixed costs $(15.8 \%)$. Credits associated with steam $(39.6 \%)$ and sulfur $(11.4 \%)$ partially offset these costs.

From the beginning, we recognized that the sorbent replacement rate equal to $1 \%$ of the sorbent circulation rate was unrealistically large. $1 \%$ replacement rate corresponds to an average sorbent life of 100 cycles, and sorbent lifetimes of several hundred cycles are thought to be necessary. In all probability, neither of the two cases presented in Table 13 would be economically viable.

The next step in the economic study will be a sensitivity analysis in which items which contribute significantly to the total cost and which involve significant uncertainty will be varied over a range of possible conditions to evaluate the effect on total annual levelized cost. Key sensitivity parameters to be considered include the unit cost and replacement rate of both the zinc and cerium sorbents. Reducing the sorbent replacement rate (increasing sorbent life) will reduce the annual levelized cost of both options, but will have a much greater effect on case 5 a since the cerium sorbent cost is so large. At some replacement rate the cost of the two options will be equal, and for still smaller replacements rates, the twostage desulfurization with $\mathrm{SO}_{2}$ regeneration case will be less expensive. In the limit as the sorbent replacement rate approaches zero, the two-stage desulfurization with $\mathrm{SO}_{2}$ regeneration option will actually become profitable since the credits for sulfur and steam exceed the total of all cost items less sorbent replacement. In contrast, there is no sorbent replacement rate at which the single-stage desulfurization with DSRP option will become profitable since by-products credits are less than the sum of the cost items less the zinc sorbent replacement cost. 
Table 13. Total Levelized Cost Comparison for Two-Stage Desulfurization With $\mathrm{SO}_{2}$ Regeneration (Case 5a) and Single-Stage Desulfurization With-DSRP

(Case 6): $10^{6} \$, 65 \%$ Capacity Factor.

Two-Stage Desulfurization With $\mathrm{SO}_{2}$ Regeneration (Case 5a)

Fixed Cost

Operating Cost (Credit)

Fixed Operating Cost

Zinc Sorbent

Cerium Sorbent

DSRP Catalyst

Coal Gas

Nitrogen

Oxygen

Sulfur

Steam

Boiler Feed Water

Electricity

Total Levelized Cost
Total Capital Requirement

$$
6.70
$$

Annual Cost

0.24

0.41

21.42

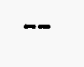

$--$

$-$

0.65

(1.34)

(3.91)

1.05

0.11
Levelized
Cost

1.31

0.31

0.54

28.29

$-$

$-$

$-$

0.86

(1.77)

(5.17)

1.39

0.15

25.91

$\%$ of Levelized
Cost

5.1

1.2

2.1

109.2

$-$

$-$

$-$

3.3

(6.8)

(20.0)

5.4

0.6

100
Single-Stage Desulfurization With DSRP (Case 6)
Levelized

Cost

2.58

Annual Cost

$$
0.48
$$

0.63

11.38

--

0.005

4.11

2.91

(1.86)

(6.45)

1.62

1.38

16.30
$\%$ of Levelized Cost

15.8

69.8

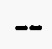

0.0

25.2

17.8

(11.4)

(39.6)

9.9

8.5

100 


\section{REFERENCES}

Bevan, D.J.M. and J. Kordis, 1964, Mixed Oxides of the Type $\mathrm{Mo}_{2} \mathrm{O}_{3}-\mathrm{I}$. Oxygen Dissociation Pressure and Phase Relationship in the System $\mathrm{CeO}_{2}-\mathrm{Ce}_{2} \mathrm{O}_{3}$ at High Temperatures, J. Inorg. Nucl. Chem., 26, 1509.

Buchanan, T.L., et al., 1994, Optimization of Gas Stream Cleanup in Three IGCC Systems, Final Report, Task Assignment No. 11, DE-AC01-88FE61660.

Chen, H.T., et al., 1991, Sensitivity Effect of Sulfur Control on IGCC Cost of Electricity, Final Report, Task Assignment 2, DE-AC01-88FE361662.

Donsi, G., et al., 1983, "Heat Transfer from Vertical Heated Surfaces to Slugging, Pressurized Fluidized Beds," Fluidization, Proceedings of the Fourth International Conference on Fluidization, Kashikojima, Japan.

Electric Power Research Institute, 1982, "TAG- Technical Assessment Guide," Report No. EPRI-P-2410-SR.

Gangwal, S.K., 1993, "Slipstream Testing of Hot-Gas Desulfurization with Sulfur Recovery," Proceedings of the Advanced Coal-Fired Power Systems '93 Review Meeting, Vol 1, p 220 (DE-AC21-93MC30010)

Kern, D.Q., 1950, Process Heat Transfer, McGraw-Hill, New York

Kirk-Othmer Encyclopedia of Chemical Technology, 1978, Wiley, New York

McMichael, W.J., and S.K. Gangwal, 1991, Recovery of Sulfur from Hot Gas Desulfurization Processes, Final Report, DE-AC21-86MC23260.

Meng, V.V., and D.A.R. Kay, 1987, Gaseous Desulfurization Using Rare Earth Oxides, in High Tech Ceramics, P. Vincenzini, ed., Elsevier Science Publishers, Amsterdam, p. 2247.

Milton, P., 1996, Personal Communication, A.P. Green Industries, Inc., Gonzales, Louisiana.

O’Hara, J.B., et al., 1987, "Sulfur Recovery from Hot Coal Gas Desulfurization Processes," DOE/MC/21097-2338(DE 87006477).

Peters, M., and K. Timmerhaus, 1991, Plant Design and Economics for Chemical Engineers, 4th ed., McGraw-Hill, New York. 


\section{Disclaimer}

This report was prepared as an account of work sponsored by an agency of the United States Government. Neither the United States Government nor any agency thereof, nor any of their employees, makes any warranty, express or implied, or assumes any legal liability or responsibility for the accuracy, completeness, or usefulness of any information, apparatus, product, or process disclosed, or represents that its use would not infringe privately owned rights. Reference herein to any specific commercial product, process, or service by trade name, trademark, manufacturer, or otherwise does not necessarily constitute or imply its endorsement, recommendation, or favoring by the United States Government or any agency thereof. The views and opinions of authors expressed herein do not necessarily state or reflect those of the United States Government or any agency thereof. 